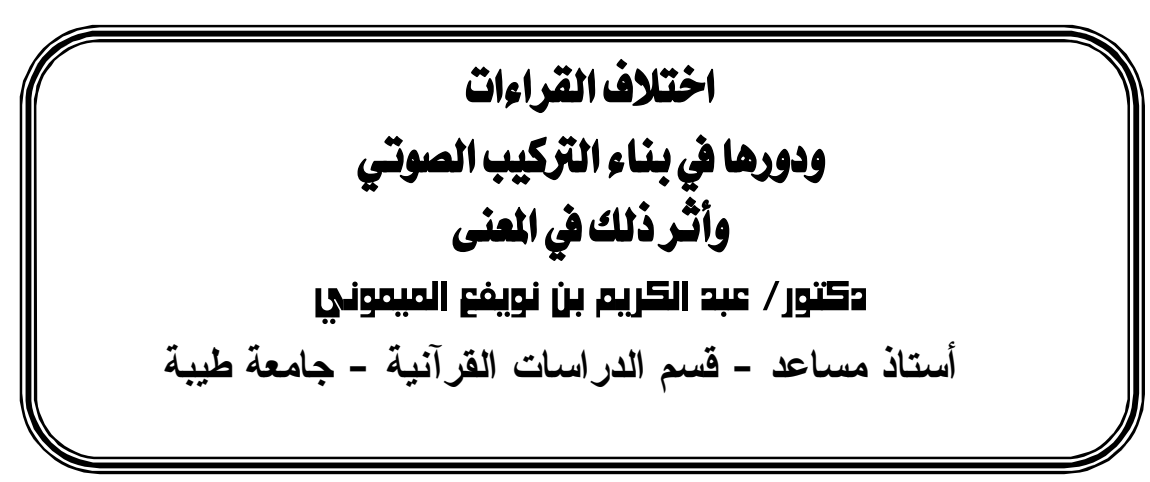

\title{
ملخص الموضوع:
}

يتعرض البحث لعلاقة التركيب الصوتي باختلاف القراءات القر آنية ويتكون من خطة

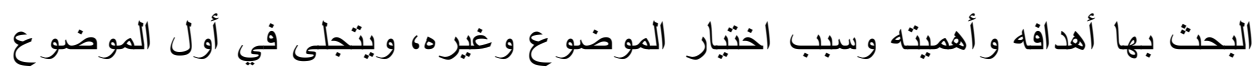

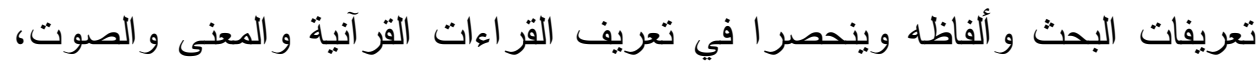

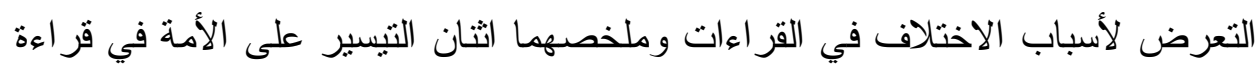

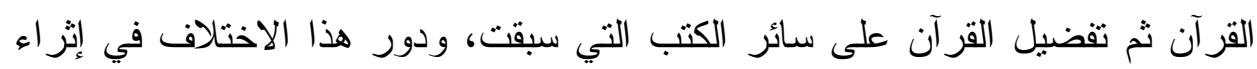
المعنى الدلالتي و التركيب الصوتي، ثم دور اختلاف القر اءة في بناء التزكيب الصوتي ولئي

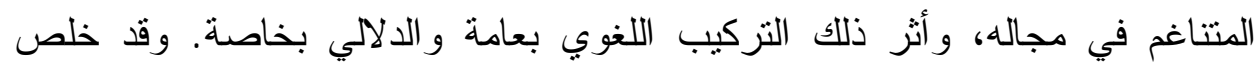

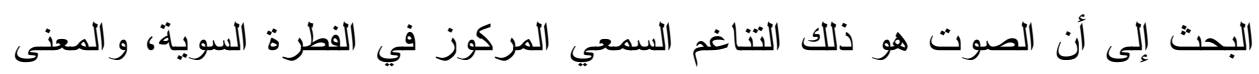

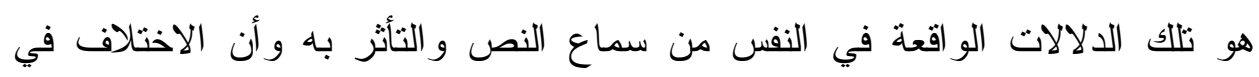
القراءات القر آنية يثري النص القر آني بمعان جديدة تسهم في النواحي الفقهية و اللغوية

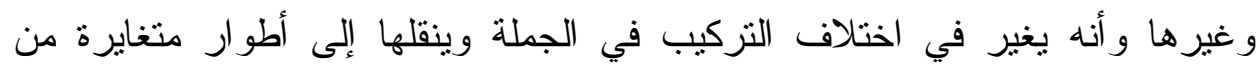
التعبير في الصورة المعنوية المتقاربة ، وقد أدى ذلك إلى نشأة دلالات أكثر في التعبير و آثر في أحيان في الترجيح الفقهي و اللغوي. 


\section{Abstract:}

The current research investigates the relationship of phonemic composition to the different Qur'anic readings and falls into research plan with its aims, significance, motivation for choosing the topic, and others. At the beginning of the topic the research's definitions and wording are reflected and are limited to the definition of Qur'anic readings, meaning, and sound. The research highlights reasons for these differences, briefly attributed to two reasons: making it easy for the ummah to read the Qur' an, then preferring the Qur'an to other books that preceded it, and the role of this difference in enriching the semantic meaning and phonemic composition, then the role of the difference in reading in building the harmonious phonemic composition in its field, and the effect of that linguistic structure in general and semantic in particular. The research concluded that the sound is that auditory harmony focused on the normal instinct, and the meaning is those connotations that occur in the soul as a result of hearing the text and being influenced by it, and that the difference in the Qur'anic readings enriches the Qur'anic text with new meanings that contribute to the jurisprudential, linguistic and other aspects, and that it changes the different composition in the sentence and it transfers them to different stages of expression in the convergent moral form. This has led to the emergence of more connotations in expression and sometimes more in the jurisprudential and linguistic weighting.

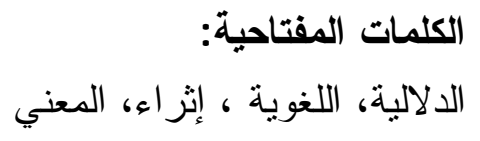




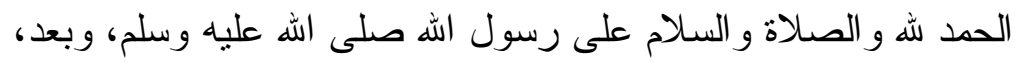

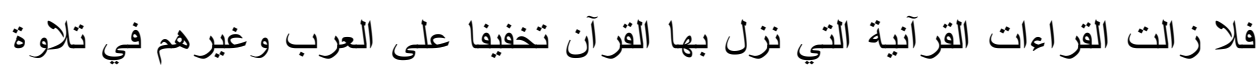

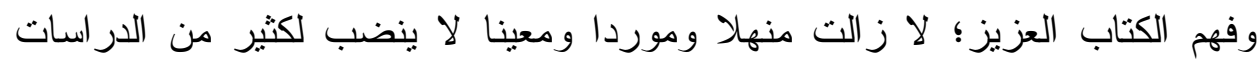

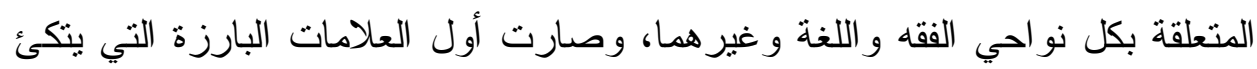

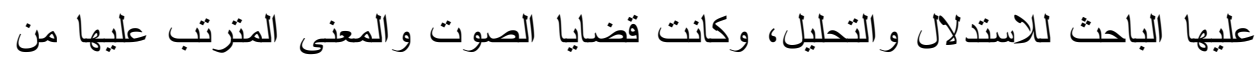

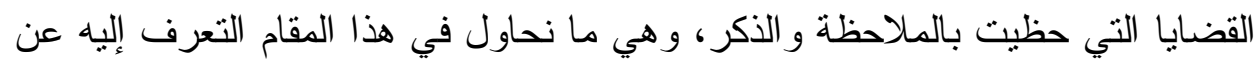

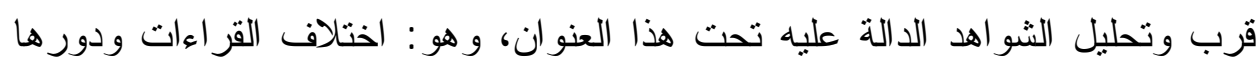
في بناء التركيب الصوتي و أثر ذلك في المعنى. أهمية الموضوع: تتبع أهمية الموضوع الموضوعة وفاعليته في:

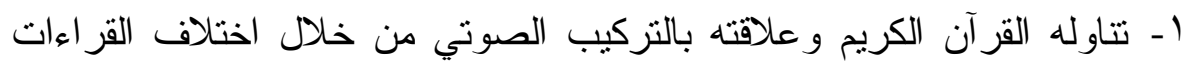

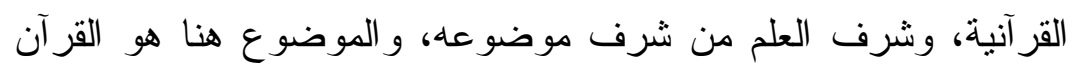
الكريم.

r- أن الأهمية تتبع من كون البحث بركز في ناحية التركيب الصوتي، وهي قضية شغلت بال القدماء و المحدثين.

r- أنه يتأتى من ور اء البحث فو ائد لغوية وفقهية و عقدية هامة نافعة في مجالها. سبب اختيار الموضوع: البحث علاقة القرآن عامة و القراءات القرآنية بخاصة بالتركيب بعامة و الصوتي بخاصة وهو موضو ع قديم حديث فيه زخم تر اثي لا ينكر ، وربط ذلك بالقر آن الكريم. وكون الموضوع من المسائل الثيقة في الدر اسة و التحليل.

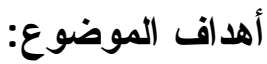

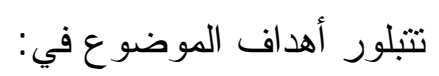
ا - إثبات أن اختلاف القر اءات تؤثز في التركيب الصوتي للجمل العربية وبالتالي في المعاني و الدلالات. r- إثبات وجه من وجوه الإعجاز القر آني الباهر، وهو أهم وجه فيه وهو الإعجاز

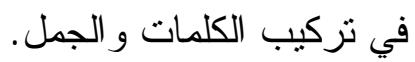


المنهج الاستقرائي التحليلي من خلال استقراء الآيات والقراءات المتواترة من سور القر آن وتسليط الضوء على علاقتها بالتركيب الصوتي للجمل التي فيها اختلاف وأثره

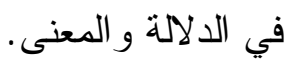
مصطلحات الموضوع تم التعريف بهما في البحث، و أهمها التعريف بالقر اءات القر آنية و المعنى و الصوت . الار اسات السابقة:

بعد البحث و التحري وجدت مقالات وكتابات في جو انب أخرى غير ما كتبنا فيه مثل : (التغيير ات الصوتية في القراءات القر آنية) مركز تفسير للار اسات القر آنية.

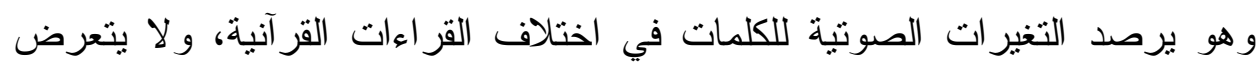
للتركيب داخل الجمل و أثز الاختلاف فيه. (الظو اهر الصوتية وتجلياتها في القراءات القر آنية) . د جميلة روقاب موقع: أقلام الهند

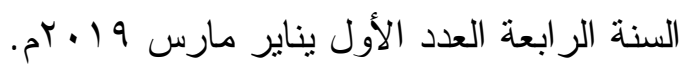

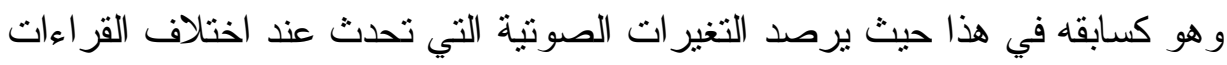

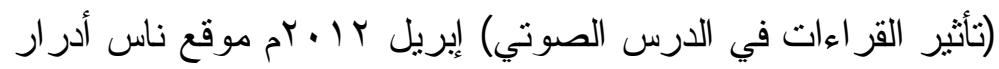

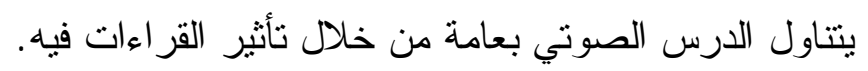
أما البحث موضو عنا فيتعرض لتتاسق التركيب و اختلاف ذلك التتاسق إلى غيره

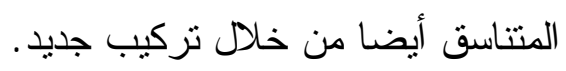

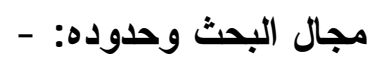
القرآن الكريم في قر اءاته المتو اترة مع تفسير ذللك وعلاقته بالتركيب الصوتي للجمل.

\section{خطة البحث}

*قع البحث في تمهيد ومبحثين: البحث:

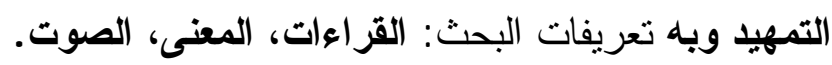

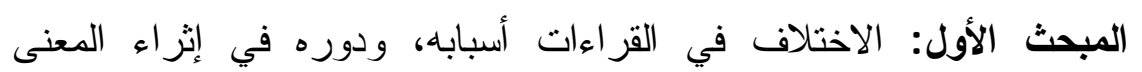
و التزكيب . المطلب الأول: أسباب الاختلاف في القراءات القرآنية. 


$$
\text { المطلب الثاني: دور الاختلاف في إثر اء المعنى و التزكيب. }
$$

المبحث الثاني: دور القراءات في بناء التركيب الصوتي وآثاره اللغوية

$$
\begin{aligned}
& \text { المطلب الأول: دور القر اءات في بناء التركيب الصوتي . } \\
& \text { المطلب الثاني: آثار القر اءات اللغوية و الدالالية. }
\end{aligned}
$$

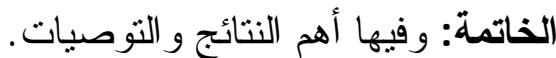

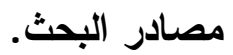


التمهيد وبه تعريفات البحث: القر اءات، المعنى، الصوت .

\section{أولا: تعريفات البحث.

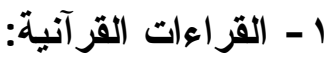

القر اءات جمع قراءة، وهي مصدر من قرأ يقر أ قر اءة وقر آنا. وقر أ الثيء:

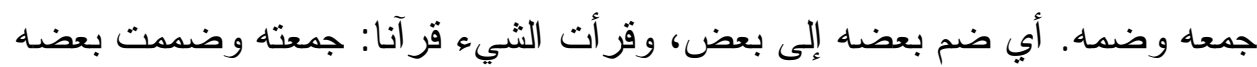
إلى بعض . (1)

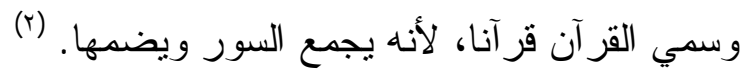

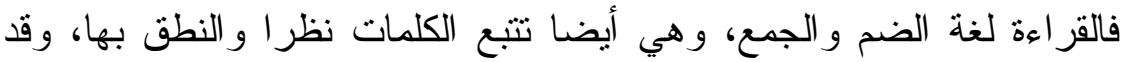

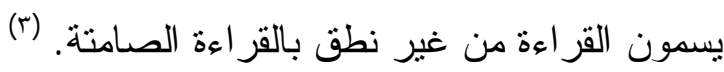
و اصطلاحا:

القر اعة للقر آن هي كيفية أداء كلمات القر آن وحروفه .

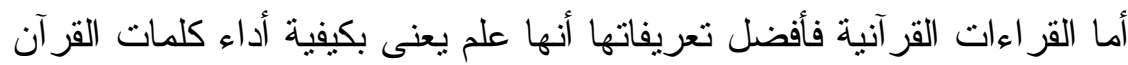

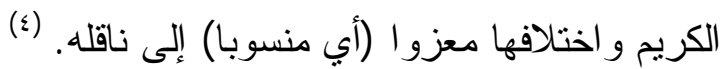

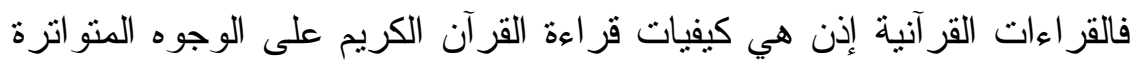
التي نزل بها على النبي صلى الله عليه وسلم. قد قسَّم أهل العلم القر اءات القر آنية إلى قسمين رئيسين هما : القر اءة الصحيحة، الصها و القر اعة الثاذة. وهي القراءة التي وافقت وجها من وجوه اللغة العربية، ووافقت الرسم العثماني ولو احتمالا، ونقلت إلينا بسند صحيح ثابت. فكل قر اعة استوفت هذه وهن الأركان

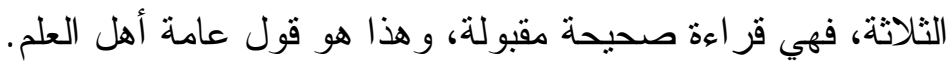
ومعنى ذلك أن شروطها ثناثة:

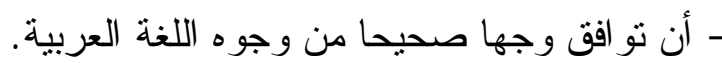

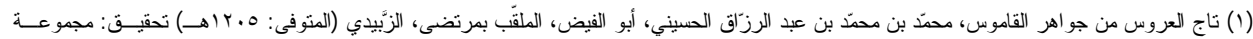

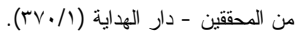

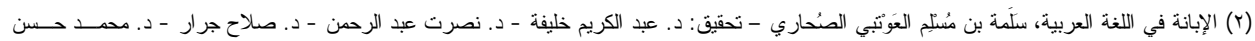

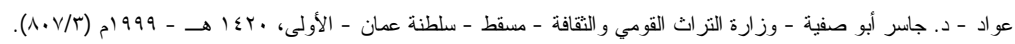

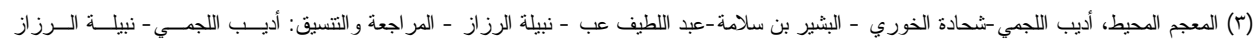

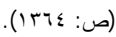

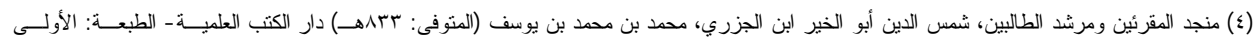


- أن نو افق القر اعة رسم مصحف عثمان رضي الله عنه.

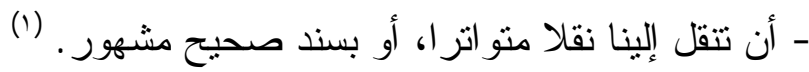
r

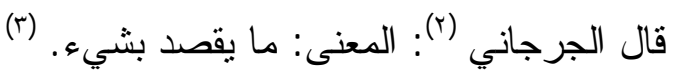
عرف العلماء المعنى بأنه المقصد المراد من الكلام الملفوظ، وهو هكذا في لهي إجمال التعريف، ويعنون به أيضا ما ير اد من ظاهر اللفظ.

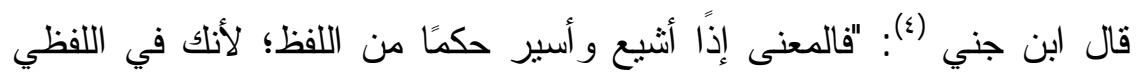
متصور لحال المعنوي ولست في المعنوي بمحتاج إلى تصور حكم اللفظي، فاعرف إنى ذلك "(0)

فالمعنى هو المتصور العلي النابع من النفس، أو المعنى شيء عام يعبر به عن مضمون اللفظ، وهو تعريف للمعنى جامع.

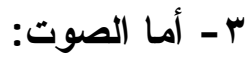

في اللغة:

فهو من صوت فلان بفلان تصويتا أي دعاه. وصات يصوت صوتا فهو صائت بمعنى صائح، وكل ضرب من الأغنيات صوت من الأصوات ـ ورجل صائت :

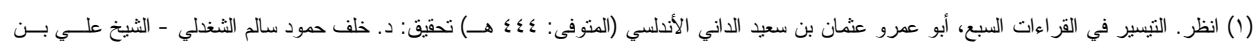

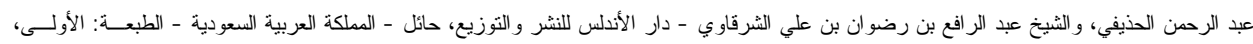

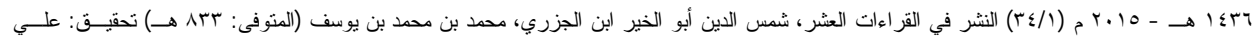

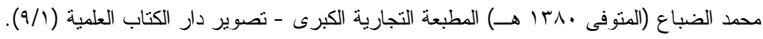

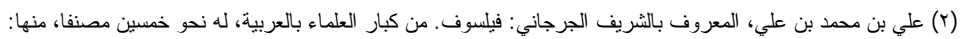

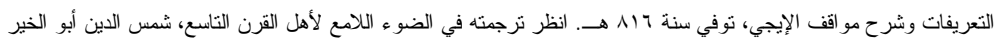

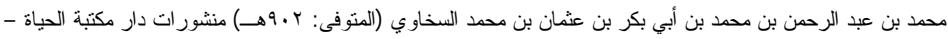

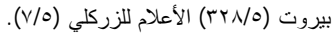

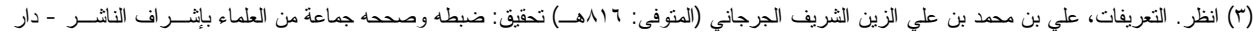

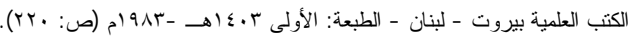

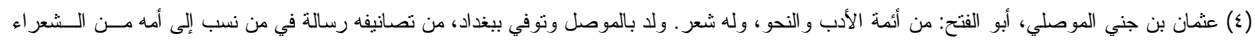

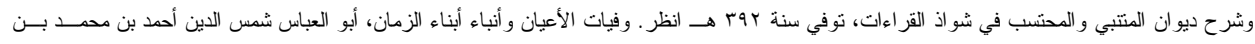

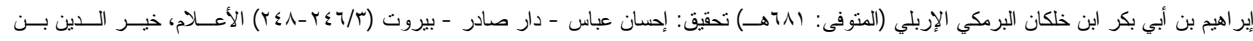

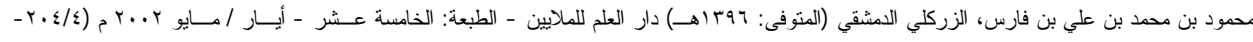


حسن الصوت شديده. ورجل صيت: حسن الصوت، وفلان حسن الصيت: له صيت وذكر في الناس حسن. (1)

و الصوت في لسان العرب و التاج: لغة: الجرس، والجمع أصوات، قيل: الصوت صوت الإنسان وغيره، والصائت: الصائح، ورجل صيّت: أي حسن شديد (r) الصوت

إذن التعاريف المبدئية للصوت تتحدث عن الجرس وهو جوهر ما يسمع، الحروف التي تخرج من الإنسان فتسمع، ما صار صدى في النفس وهو التعريف

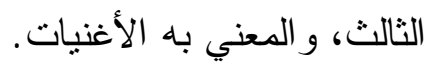

\section{وفي الاصطلاح:}

يرتبط بمصادر ينبع منه غير هذه، ويتعين المراد منه بحركة آلية في أعضاء

النطق؛

لذا يعطي الر اغب الأصفهاني (r) خلاصة دقيقة لهذه المصادر فيقول : "الصوت : هو الهو اء المنضغط عن قرع جسمين، وذلك ضربان: صوت مجرد عن تتفس بثيء كالصوت الممتد، وتتفس بصوت ما، المتتفس ضربان: غير اختياري: كما يكون من هن

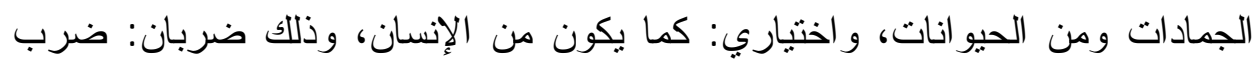

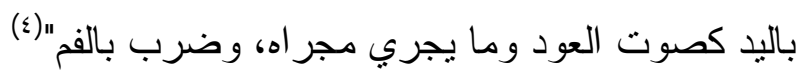

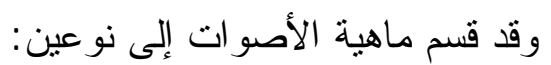

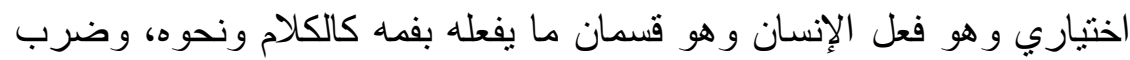

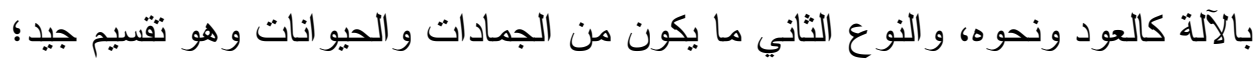

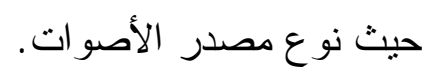

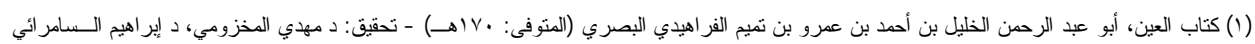

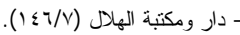

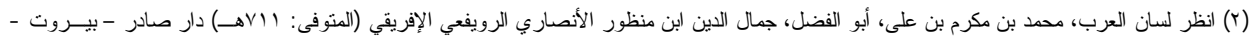

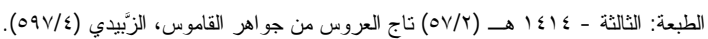

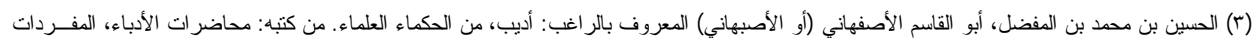

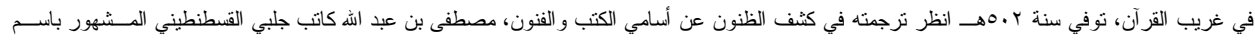

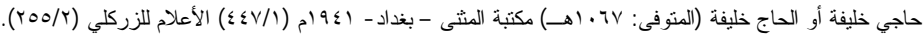

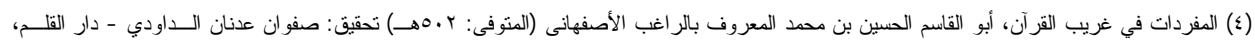

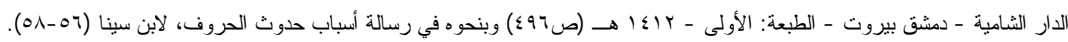


المبحث الأول: الاختلاف في القراعات أسبابه، ودوره في إثراء المعنى والتركيب.

$$
\text { تقديم: - تالاول: }
$$

يقع الاختلاف في الوجود في كل شيء أوجده الله لنا، وهذا الاختلاف فال عنه

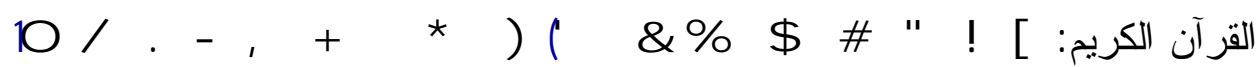

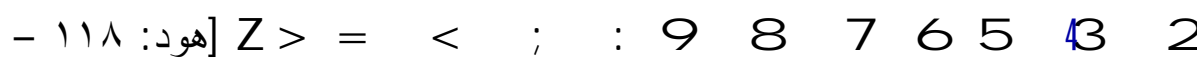
119] والاختلاف في القراءات القرآنية هو من الأمور الملفتة للنظر في شريعتتا

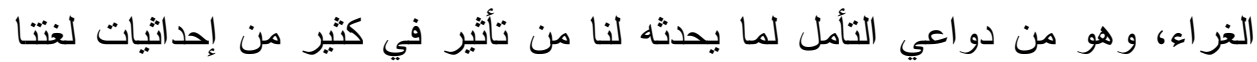
وتفسير القر آن وعدد من أنواع العلم الثرعي و اللغوي، وأكثر ما يحدثه هو الإثراء في في فئي

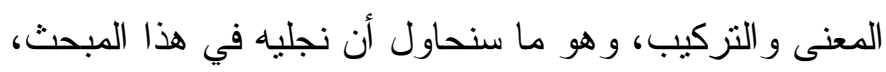

وهو في مطلبين: -

ا -المطلب الأول: - أسباب الاختلاف في القر اءات القر آنية. r -المطلب الثاني: - دور الاختلاف في إثراء المعنى و التركيب. لمطلب الأول

\section{أسباب الاختلاف في القراعات القرل آنية.}

يقرر من خلا البحث أن الأحرف السبعة جميعها قرآن نزل من آن عندان الله سبحانه وتعالى، وأنه لا مجال للاجتهاد فيها، ثم إنه من المقرر أيضا أن العلماء ذكروا

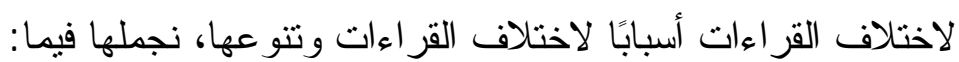
أولا: - إرادة التخفيف والتيسير على الأمة. هذا السبب تكاد تجتمع عليه كلمة أهل العلم في هذه المسالة وذللك تماثيا مع الامه

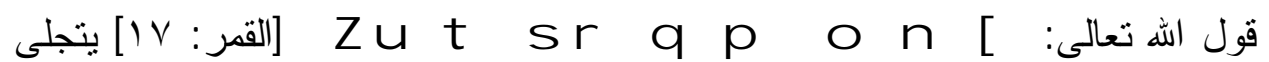

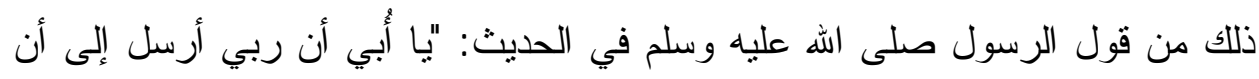
أقر أ القر آن على حرف فرل الردول هـى اليه أن هون على أمتي" إلخ.

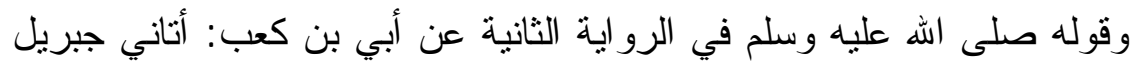
فقال: اقرأ القر آن على حرف واحد، فقلت: إن أمتي لا تستطيع ذلك حتى قال : "اقر أ

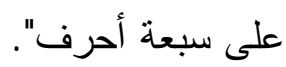


قوله صلى الله عليه وسلم في الحديث الرابع: "اسأل الله معاناته ومغفرته و أن

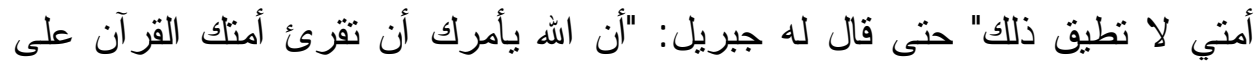

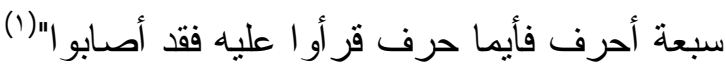

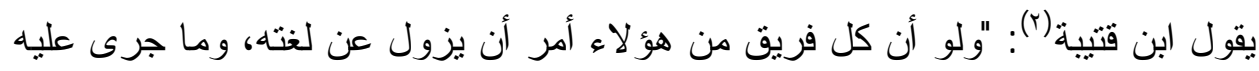

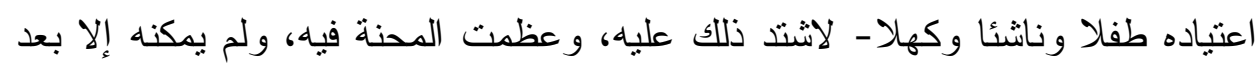

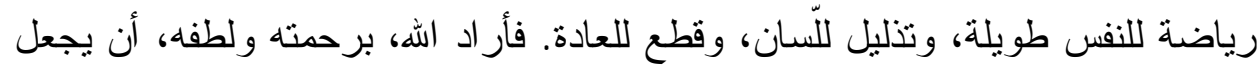

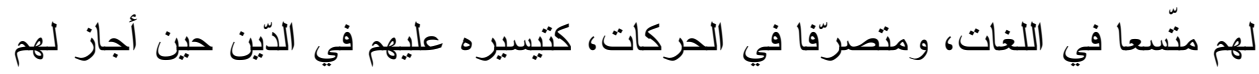

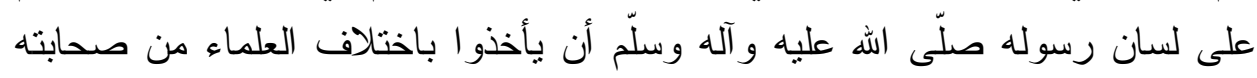

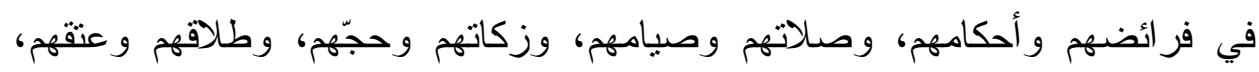

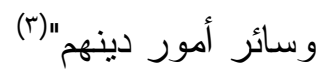
يقول ابن تيمية(ء) :"قول السائل ما السبب الذي أوجب الاختلاف بين القر اء فيما احتمله

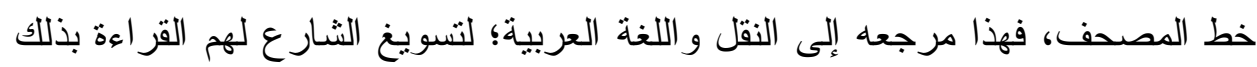

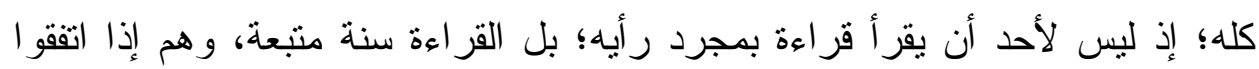
على اتباع القر آن المكتوب في المصحف الأمامي، وقد قر أ بعضهم بالياء وبعضهم

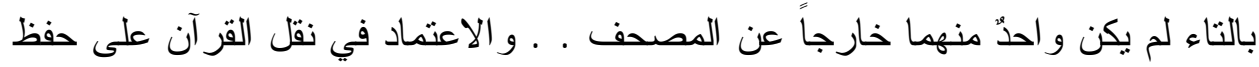

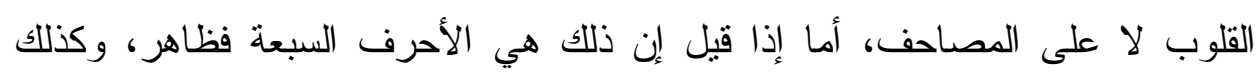

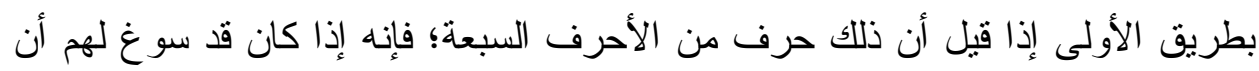

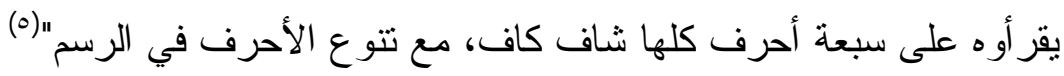

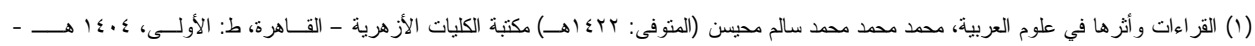

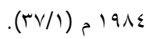

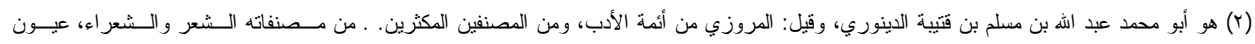

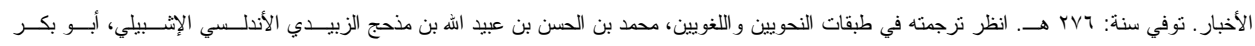

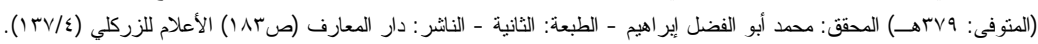

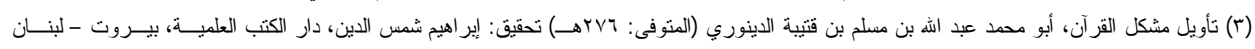
(ص: (ص r (r).

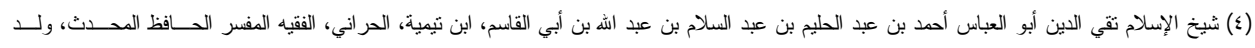

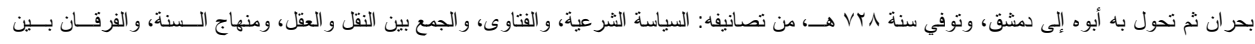

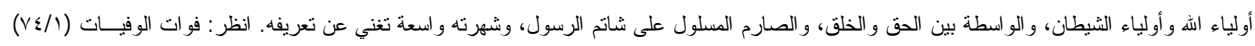


وكما نرى فقد بين الثيخ - رحمه الله - أن السبب الموجب لتنوع القراءات

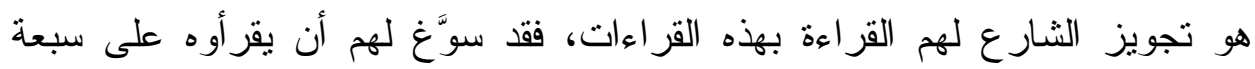

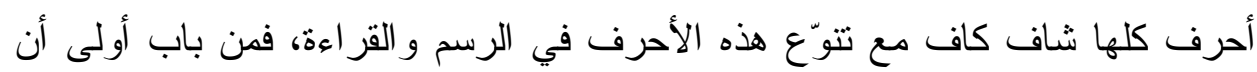

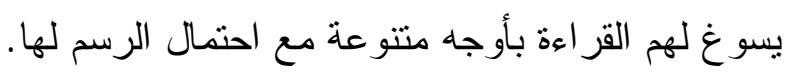

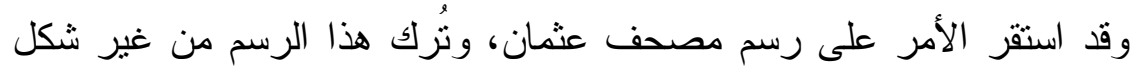

ولا نقط، لتكون صورة الرسم محتملة لأوجه القر اءة. (1)

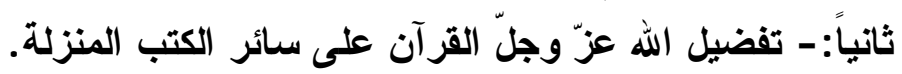

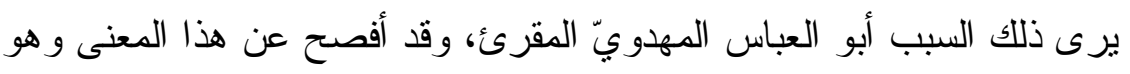
يجيب على سؤال افترضه بقوله: "إن قال قائل: ما سبب هذا الاختلاف الذي كثر بين القر اء في ألفاظ القرآن؟ قيل له: سببه تفضيل الله عزّ وجلّ القرآن على سائر الكتب فئب

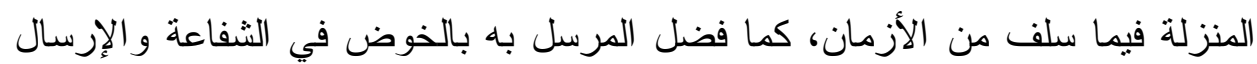
إلى الجماعة مما كان على عهده من العرب و العجم ومن بعدهم من الأمم، و إظهار دينه

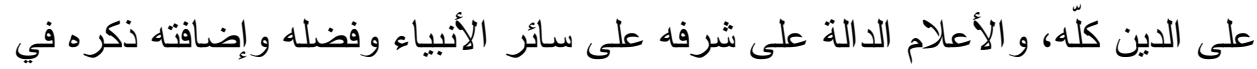

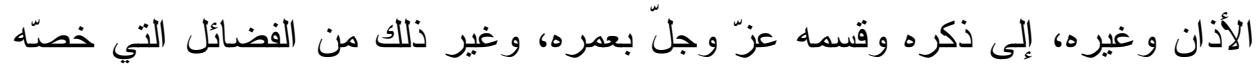

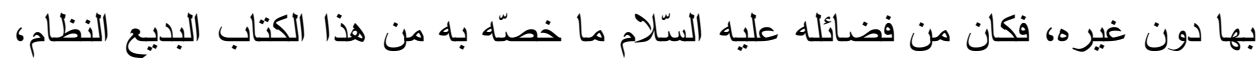

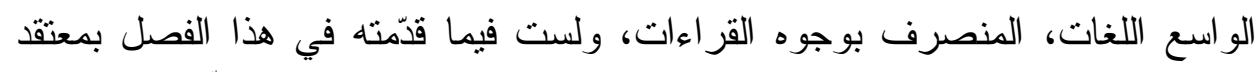

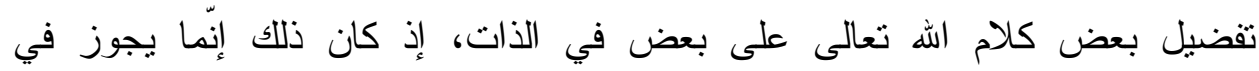
المخلوقات، لكن لمّا كان الأجر يزيد بزيادة القراءات واتساع اللغات لفئ، أطلقنا التفضيل

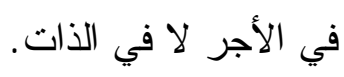

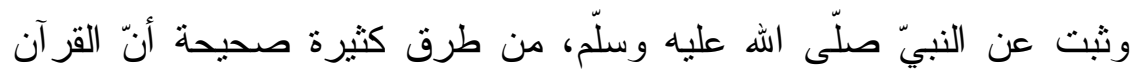
أنزل على سبعة أحرف، واختلف الناس في معنى هذا الحديث اختلافا كثيرًا، فأكثرهم

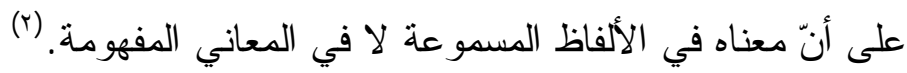

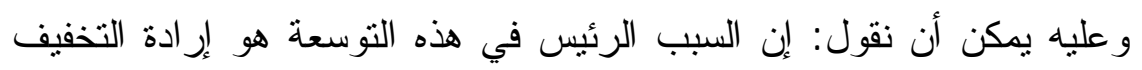

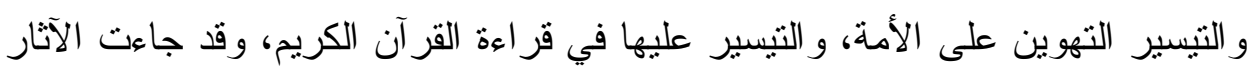

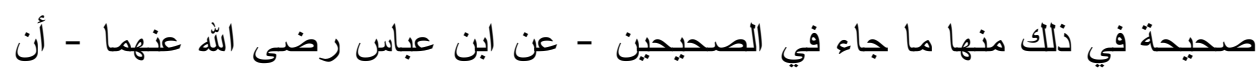


رسول الله - صلى الله عليه وسلم - قال : " أقرأني جبريل على حرف فر اجعته، فلم أزل أستزيده ويزيدني حتى انتهى إلى سبعة أحرف" (1) وز اد مسلم: " قال ابن شهاب:

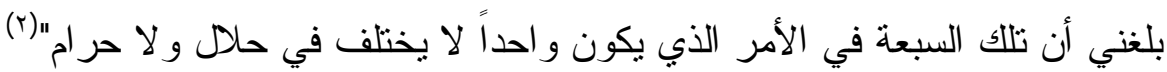

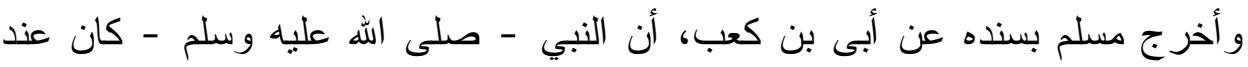

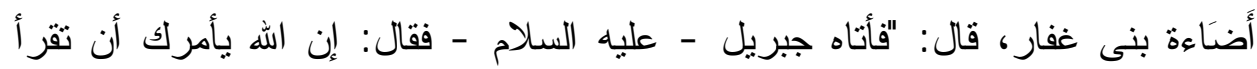

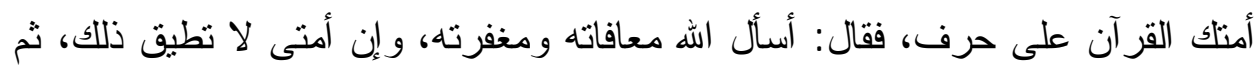

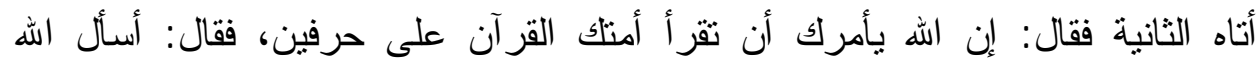

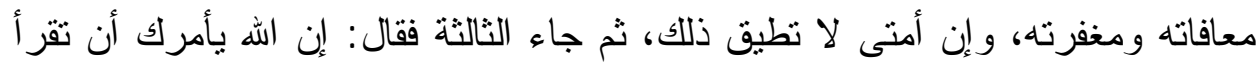

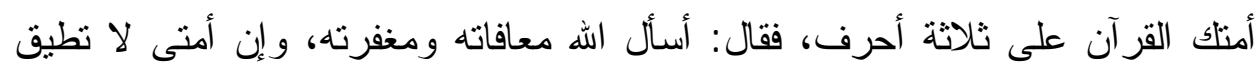

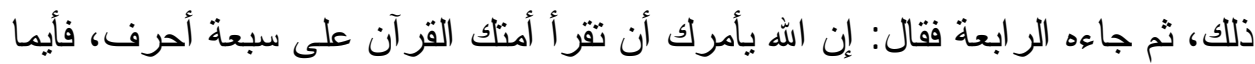

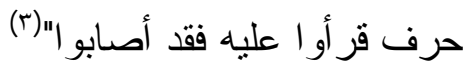
وقد جمع بعض المتأخرين أسبابًا منتوعة في اختلاف القر اءات، منها الصحيح

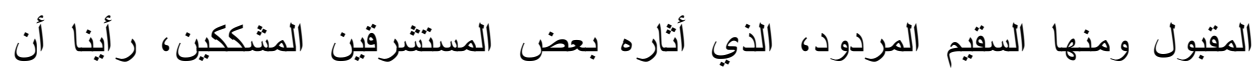
نسوقها في نهاية المطلب نتبيهًا على عو ارها، وقد كفانا الرد عليها كبار أهل العلم . فيقول صاحب صفحات في علوم القراءات : "ذكر بعض الناس أسبابًا متعددة

$$
\text { في اختلاف القر اءات؛ منها: }
$$

ثالثاً: - اختلاف قراءة أتها: النبي صلى الله عليه وسلم:

فقد ورد أنه صلى الله عليه وسلم لم يلتزم عند تعليمه القرآن للمسلمين لفظكا

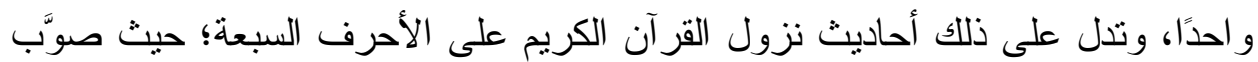
الرسول - صلى الله عليه وسلم - قر اءة كل من اختلف من الصحابة مع زميله، وقال

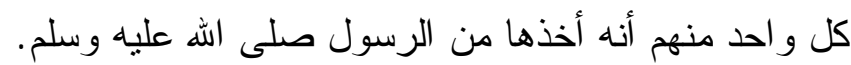
و القراءات المتو اترة بكثرتها خير دليل على ذلك؛ الته حيث إنها رُويت بأسانيدها الصحيحة المنو اترة إلى الرسول صلى الله عليه وسلم. 
رابعاً: - اختلاف تقرير النبي - صلى الله عليه وسلم - لقراعة الصحابة:

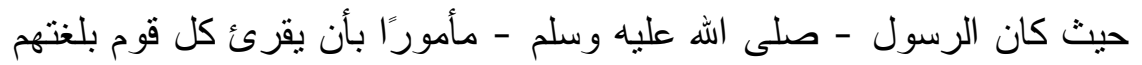
وما جرت عليه عادتهم، فالهذلي يقر أ: "عتى حين" بالعين بدل الحاء، و الأسدي يقر أ:

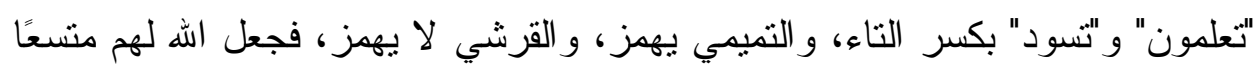
في اللغات كتيسيره عليهم في الدين .

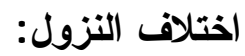

كان الرسول - صلى اله عليه وسلم - يعرض القرآن على جبريل في كل

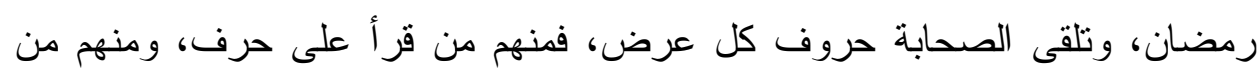
قر أ على حرف آخر، وقد اجتمعوا على عرضات أخبرة، فلم يقع الاختلاف إلا في مُفي

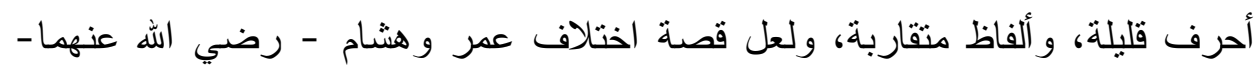
تدل على اختلاف النزول؛ حيث فيها: "كذلك أنزلت" ولهذا اختلفت المصاحف وفت وفتلف العثمانية

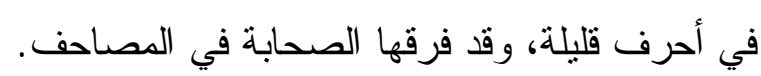
اختلاف الرواية عن الصحابة:

ذلك أن الصحابة قد اختلف أخذهم للقرآن من فِيِّ الرسول - صلى الله عليه

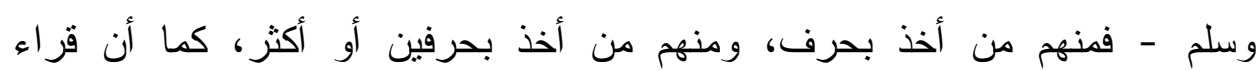

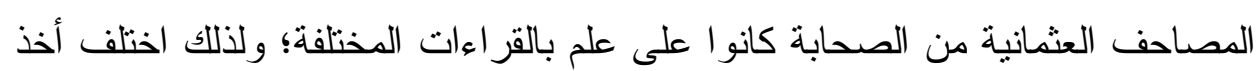

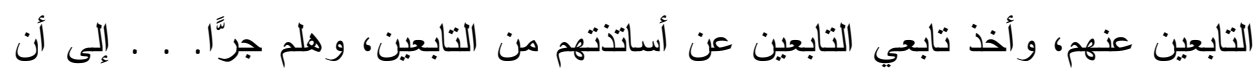

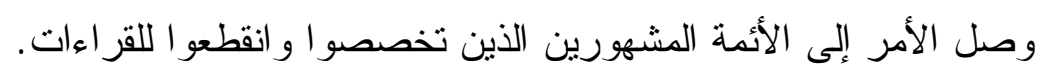
اختلاف اللغات أو اللهجات:

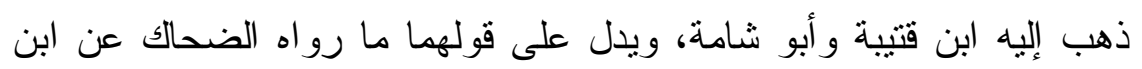

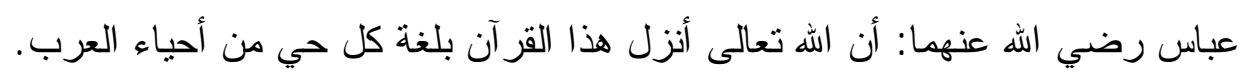

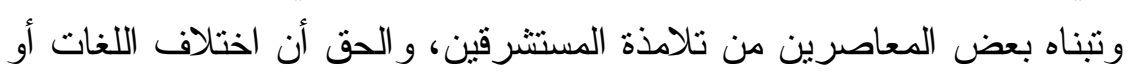
اللهجات ليس هو في جميع القراءات؛ و إنما في بعضها. 
خامساً: - عدم النقط والثكل واجتهاد القراء في هيكل الكلمات القرآنية:

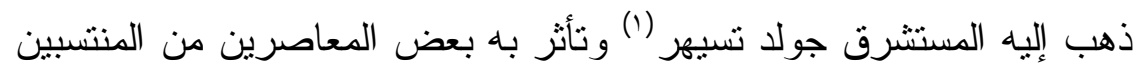

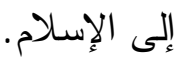

$$
\begin{aligned}
& \text { ولقد تصدَّى للرد على هؤ لاء كثيرون؛ منهم: } \\
& 1 \text { - محمد طاهر الكردي في : تاريخ القر آن. }
\end{aligned}
$$

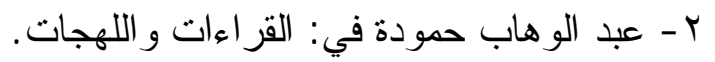

r - عبد الفتاح القاضي في: القر اءات في نظر المستشرقين و الملحدين.

\section{الخلاصة: - (أن}

إن أسباب اختلاف القر اءات ترجع إلى سببين رئيسين :

\section{-تعدد النزول:}

ويدخل فيه قر اءة النبي - صلى الله عليه وسلم -وبعض تقريره، و الكثير من

$$
\text { المروي عن الصحابة. }
$$

\section{- تعدد اللهجات:}

ويدخل فيه القليل من فعل النبي - صلى الله عليه وسلم - و الكثير من تقريره.

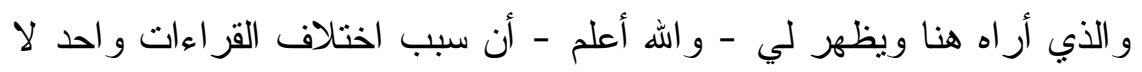

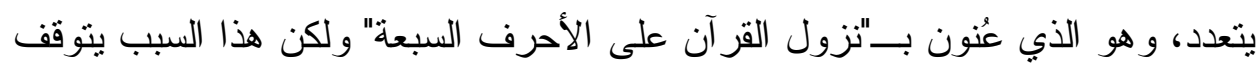

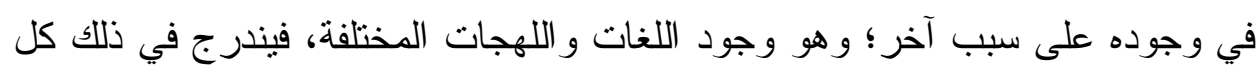

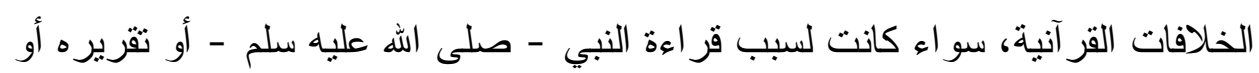

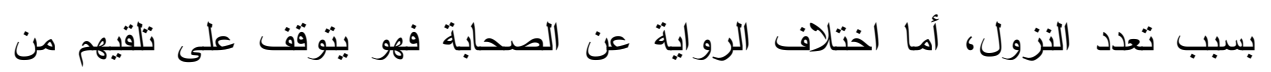
الرسول - صلى الله عليه وسلم - أو قر اعتهم عليه.

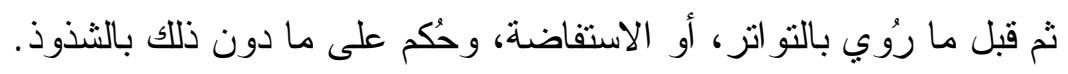

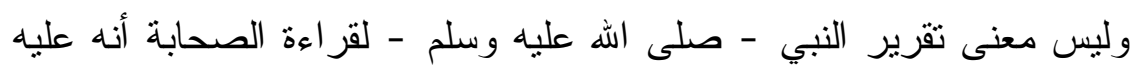
السلام كان يقرر قر اءة كل صحابي يقر أها حسب لغته ولهجته باجتهاد منه دون التلقي؛ 
وذلك لأن القرآن كله - بأحرفه المختلفة - وحي منزلّ من اله - عز وجل - لا قياس

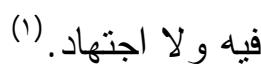
كما ساق البعض فو ائد اختلاف القراءات، وقد تتضمن في بعضها - في الوقت ذاته

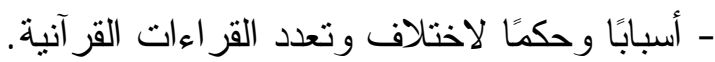

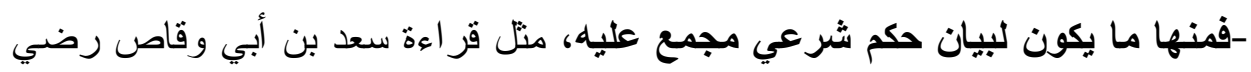

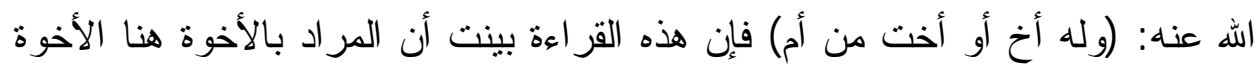
لأم، وهذا حكم مجمع عليه بين الفقهاء. ومنها: ما يكون مرجحا لحكم اختلف فيه كقر اعة: (أو تحرير رقبة مؤمنة) بزيادة: (مؤمنة)

ومنها: ما يكون للجمع بين حكمين مختلفين مثل: (يطهرون) بالتخفيف و التشديد .

ومنها: ما يكون لأجل اختلاف حكمين شرعيين، كقراءة: (وأرجلكم) بالخفض، و النصب، فقد قرأ نافع، و ابن عامر، وحفص، و والكسائي، ويعقوب بنصب الاجن

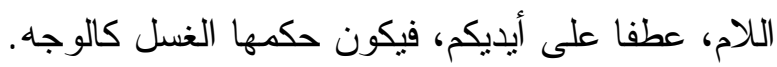
ومنها: ما يكون لإيضاح حكم يقتضي الظاهر خلافه، كقر اءة "فامضو الى الى ذكر الله" فان قر اهة: (فاسعو ا)(r) يقتضي ظاهر ها المشي السريع، وليس كذلك، فكانت القر اعة الأخرى موضحة لذلك. ومنها: ما في ذلك من عظيم البرهان، وواضح الدلالة، اذ هو مع كثرة هذا

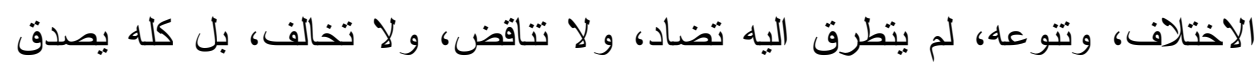

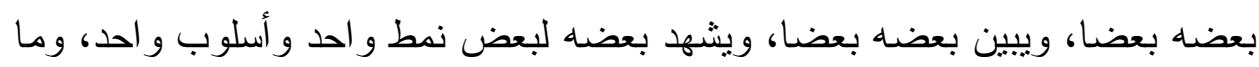

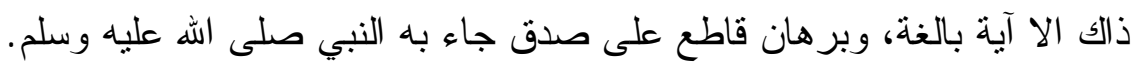

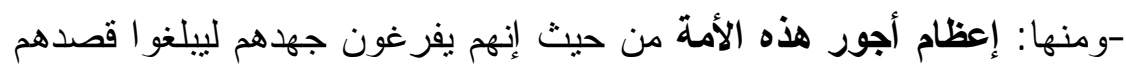

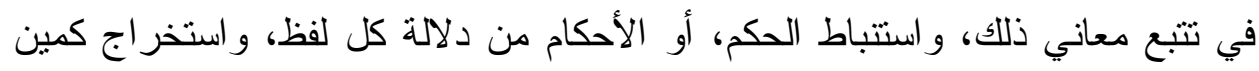


أسراره، وخفي إثنار اته، و إمعانهم النظر في الكثف عن التوجيه، و التعليل، و الترجيح، و التقصيل، بقدر ما يبلغ غاية علمهم، ويصل إليه نهاية فهمهم .

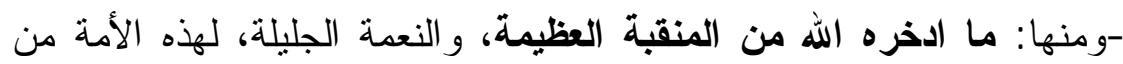

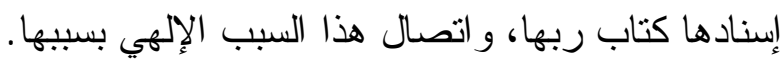

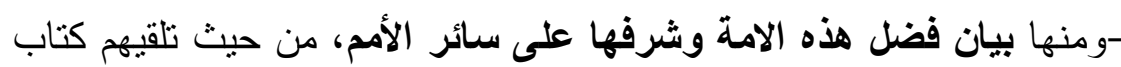

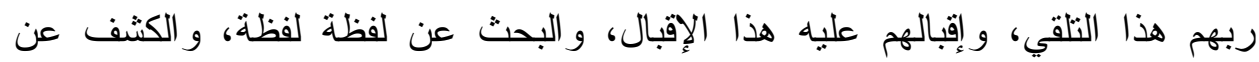

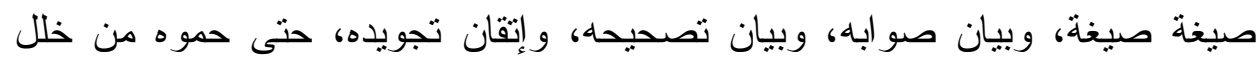

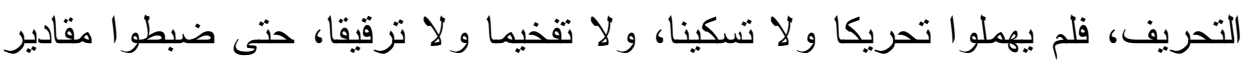

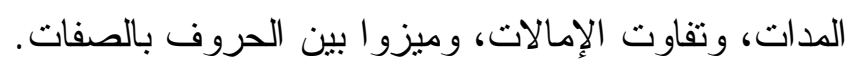

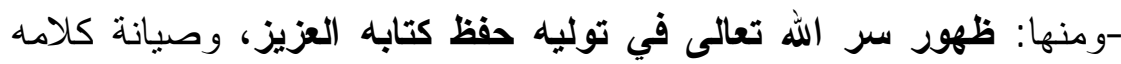

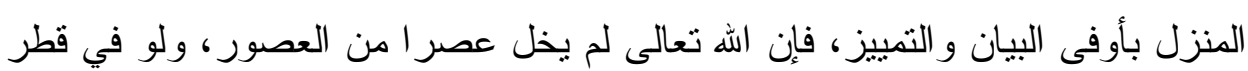

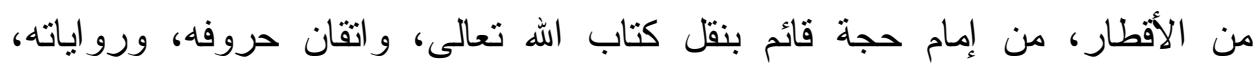

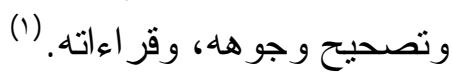
المطلب الثاني

\section{دور الاختلاف في إثراء المعنى والتركيب}

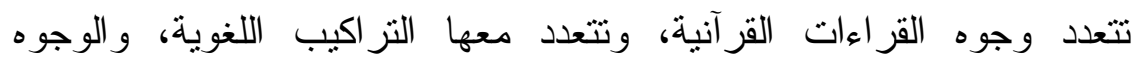
النحوية، فيكون لذلك الأثر الواضح على المعاني، ويقرر الماوردي هذا المعنى، فيؤكد

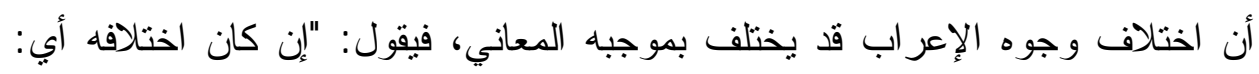

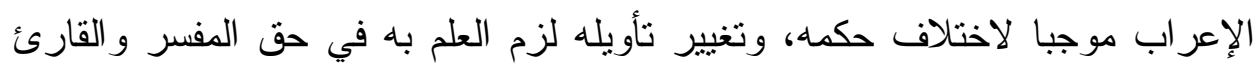

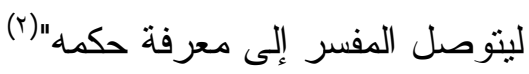

ولذلك اختلف المفسرون في استتباط المعنى المقصود و المر اد من الكلمات

القر آنية، التي جاءت على وجوه متعددة، وفي ذلك لا شك إثر اء للمعنى القر آني؛ فالآية

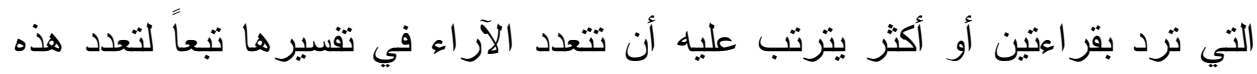

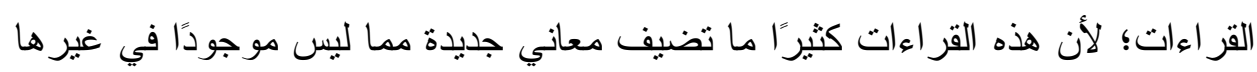

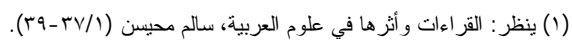

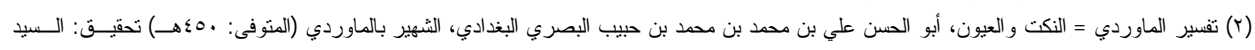

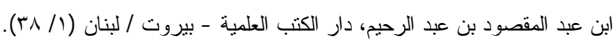


من القراءات الو اردة في نفس الآية، فيترتب على ذلك أن يتتاول بعض المفسرين الآية

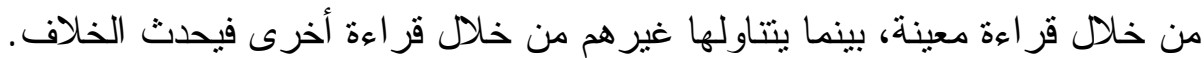

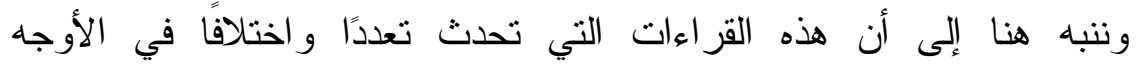
التقسيرية، قد لا تكون في درجة واحدة في بعض الأحيان، كأن يكون بعضها منو اترًا

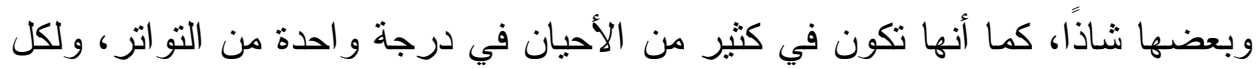

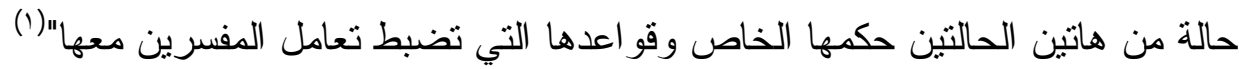
و هناك العديد من الثو اهد، التي يمكن أن نمنّل بها ليتأكد هذا المعنى، ونظرًا لثزاء صفحات القرآن بذلك، سنجمل الحديث عنها، ونصنف مجموعة الآيات القر آنية محل البحث و الاستدلال، و التي تبين الأثر المعنوي للصيغة والتركيب، تحت نقاط ثناث: :

\section{الأولى: التناوب في الفاعلية}

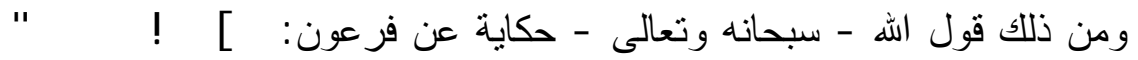
Z4 32 2 10 / . - , + + ) ( \& \% \$ \# [غافر : r7] قر أ نافع و أبو عمرو وحفص بضم الباء، وكسر الهاء، ونصب الفساد،

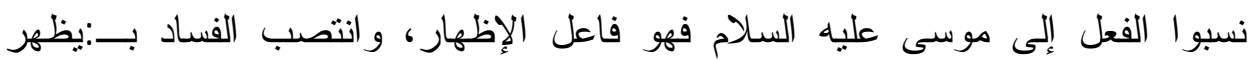

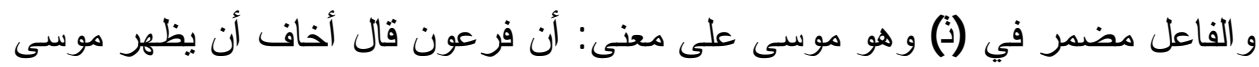

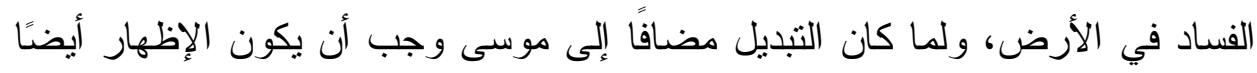

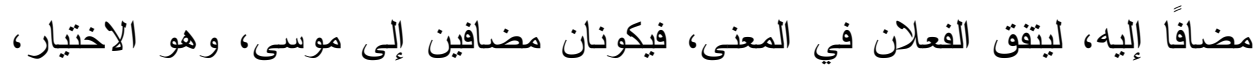

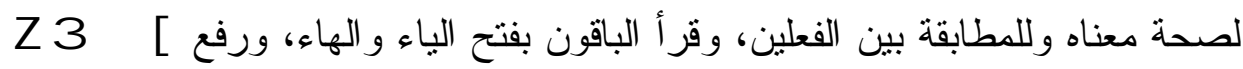
أضافوا الفعل إلى ] ] C

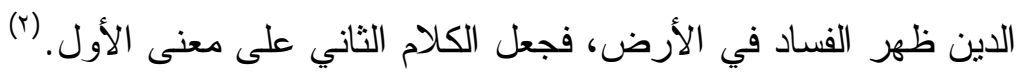

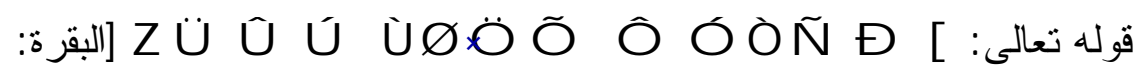

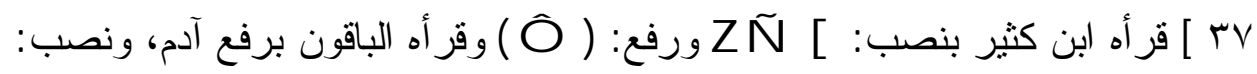


(الكلمات) ذهب بعضهم إلى استو اء المعنى، فقال : "والمعنى واحد لأن من تلقيته فقد

تنقاك" (1)

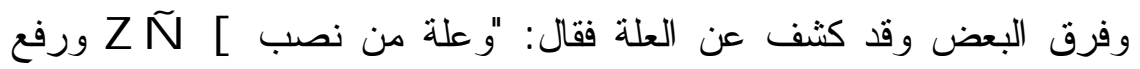

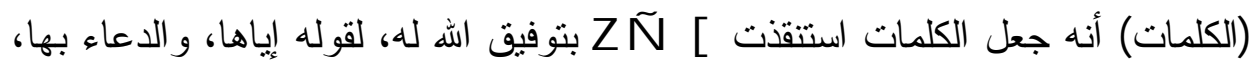
فتاب الله عليه، وأيضًا فإنه لما كان الله، جل ذكره، من أجل الكلمات تاب الله عليه، بتوفيقه إياه لقوله لها كانت هي التي أنقذته، ويسرت له التوبة من الله، فهي الفاعلة، و هي المستتقذ بها، وكان الأصل أن يقال على هذه القراءة: فتلقت آدم من ربه كلمات

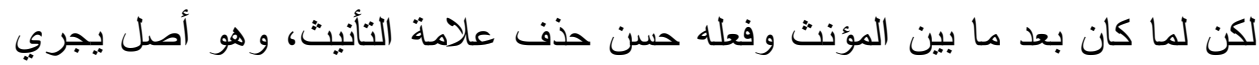

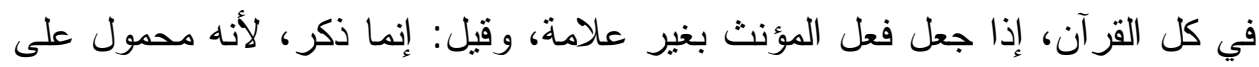

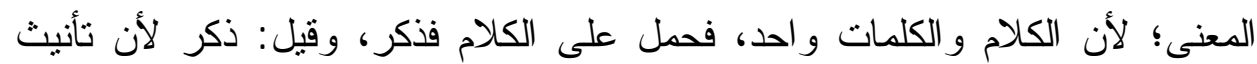
الكلمات غير حقيقي؛ إذ لا ذكر لها من لفظها، وبذلك قرأ ابن عباس ومجاهد و أهل مكة.

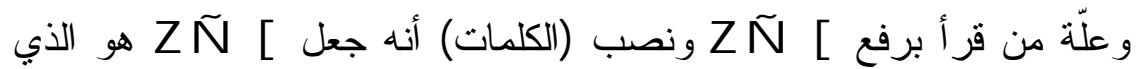
تلقى الكلمات؛ لأنه هو الذي قبلها ودعا بها، وعمل بها، فتاب الله عليه، فهو الفاعل

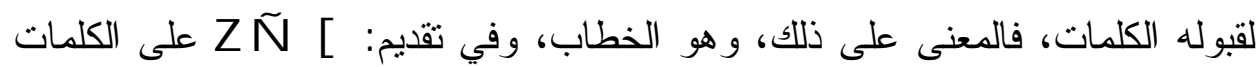

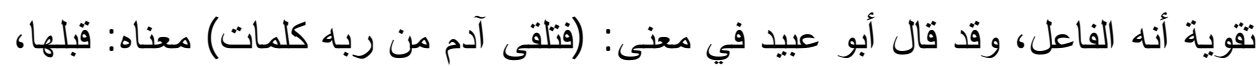

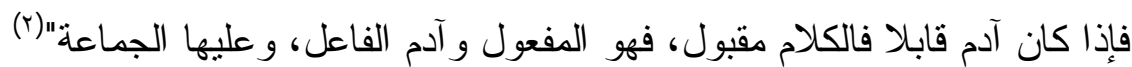

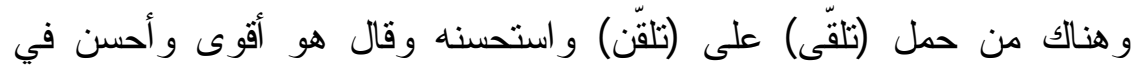

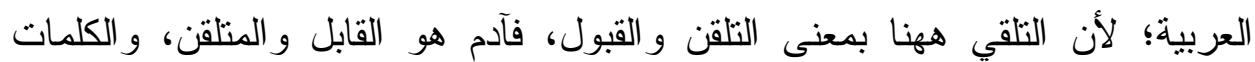

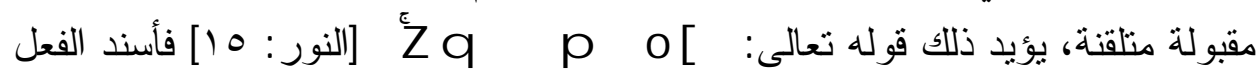
إلى المخاطبين، وجعل القول مفعو لا به.

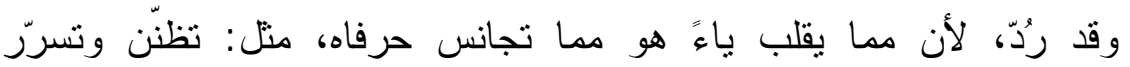

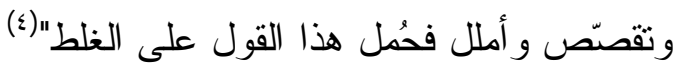

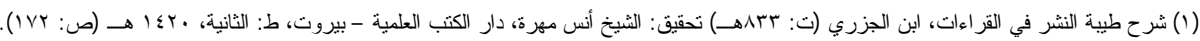

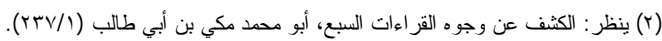

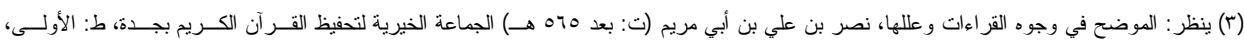

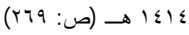

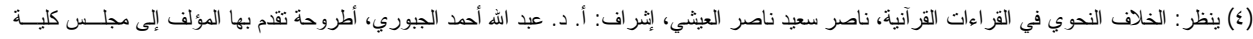

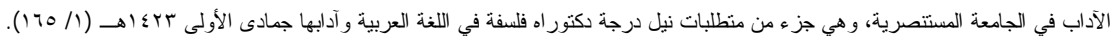


فانظر كيف كان لتقديم المفعول أو البقاء على الفاعل أو تغييره هو مظهر داع

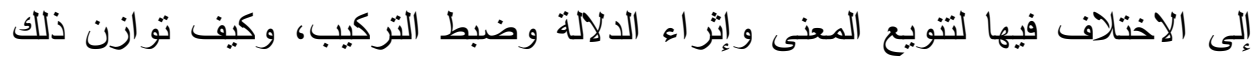
التقديم و التأخير في منظومة واحدة بحيث كل مع صنوه ليؤدي المعنى في التركيب

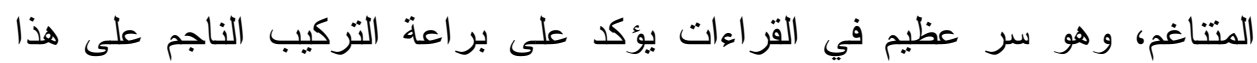
الترتيب.

الثانية: الاتصال أو القطع والابتداء

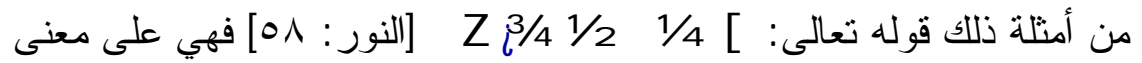
من التركيب، لا يجوز الابتداء بها وقطعها عما قبلها، لتعلقها بالبدلية في هذا المعنى،

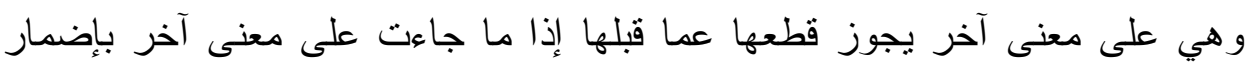

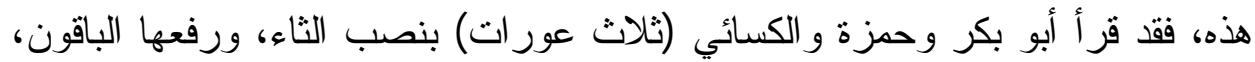

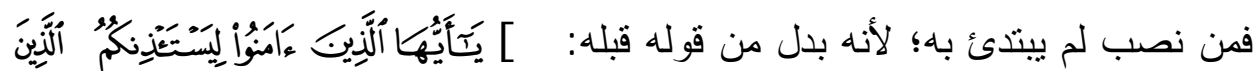

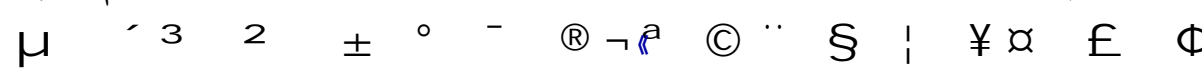

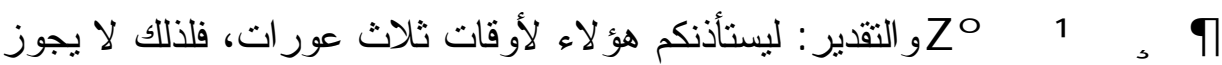
أن يقطع منه .

ومن رفع جاز لله الابتداء به لأنه مستأنف، وذللك أنه يوقعه على إضمار مبتدأ؛

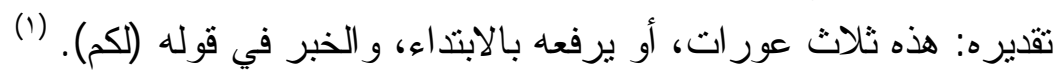

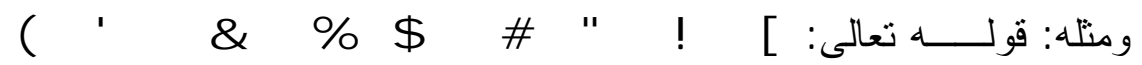

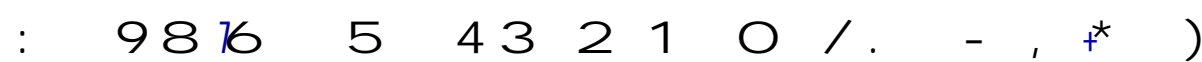
[ $[$ [البقرة: $Z<<$;

الذين في موضع رفع إن شئت بالابتداء، و التقدير : يوصون وصية. و والمعنى

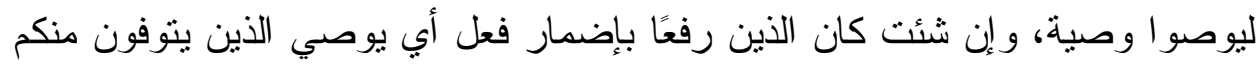
وصية، وفي الرفع وجه ثالث أبي وفيما فرض عليكم الذين ينوفون منكم ويذرون أزو اجًا يوصون وصية لأزو اجهم و الذين مبني على حال و احدة؛ لأنه لا تتم إلا بصلة ويقال: الذون في موضع الرفع. 
(1)

ومن قر أ وصية بالرفع فتقديره:و الذين يتوفون منكم عليهم وصية لأزو اجهم .

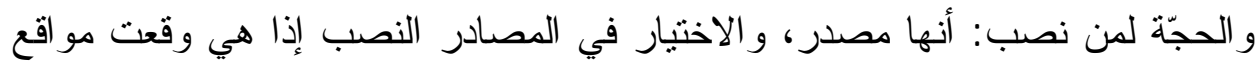

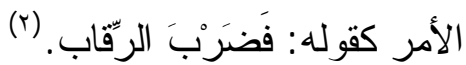
وفي هذا التزكيب يتصل صدر الآية بوصية فيتسلط عليه، كأنه قال : يوصون وصية، أو فليوصوا وصية، فالنصب يدل على معنى الأمر، و الحجة للرفع، كما فال

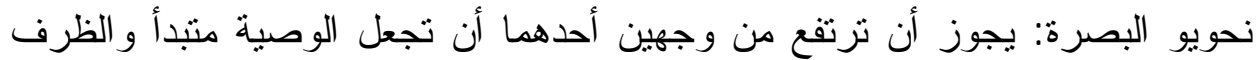

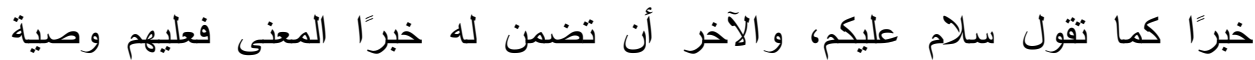

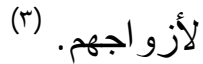
وفي هذا التركيب انقطع صدر الآية، وذلك أنه يوقعه على إضمار فيكون الخبر محذوف، بتقدير : فعليهم وصية. فحسن الابتداء بنكرة، لأنه موضع تخصيص، وعل، كما حسن "سلام عليك" ويجوز

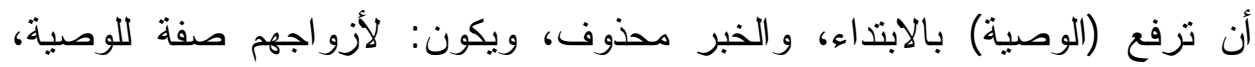
فيحسن الابتداء بنكرة، إذ هي موصوفة، و النكرات إذا وصفت حسن الابتداء بها، لما لهاء

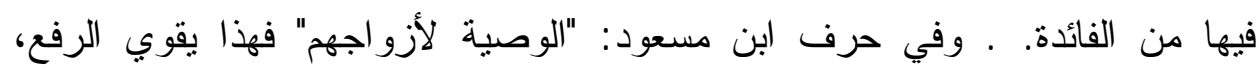

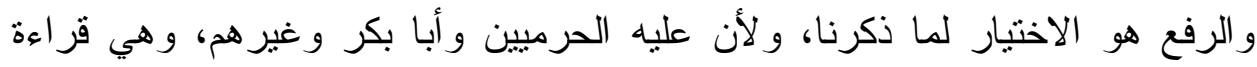

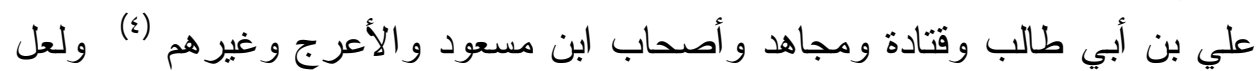

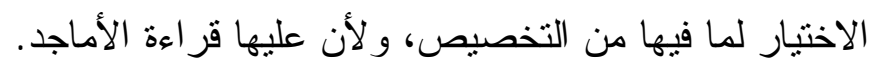

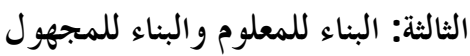

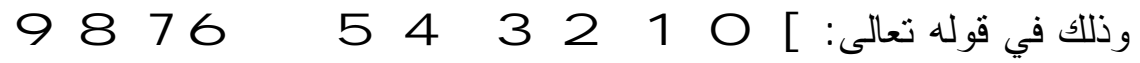

الكهف: Z : : الجبال فعل . ما لم يُسم فاعله، ولهما حجتان : أحدهما: قوله: (وسيُيرت الجبال) .

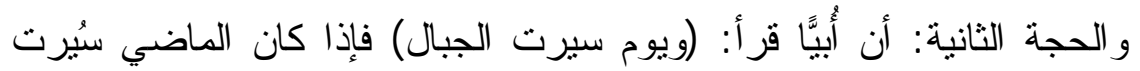

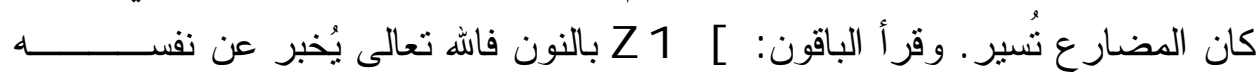




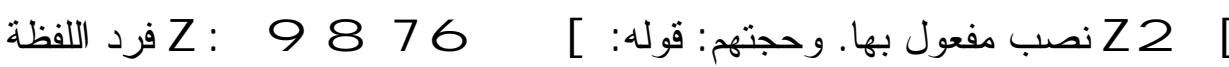

على اللفظة المجاورة لها أحسن من أن يستتهد عليها بغيرها مما بعد منه، وكلتا

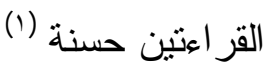

و هذا لا شكك بيان في الاستحسان الصوتي في توجيه القراءة، و النصب بإضمار

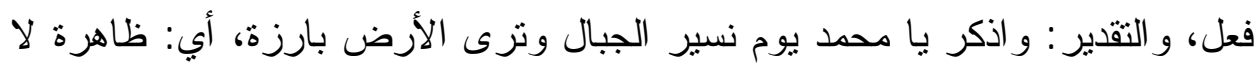

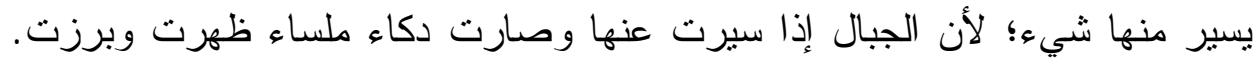

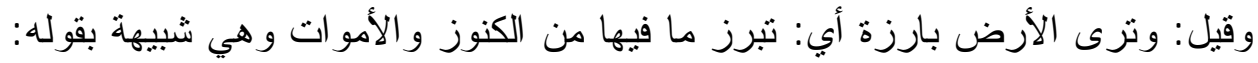

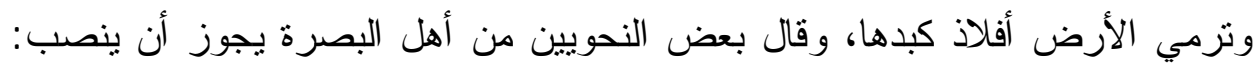

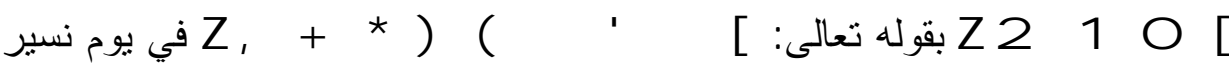

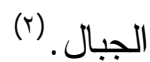

ويضاف إلى ذلك حجة أن من قرأ بالنون أنه بناه على الإخبار من الهه جل

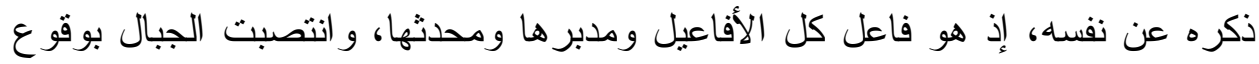

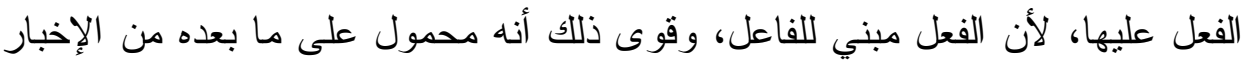

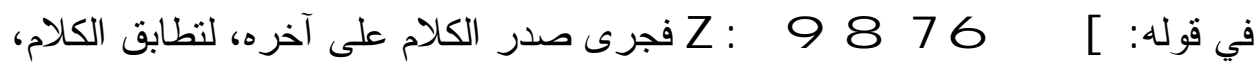
وهو الاختيار . (r)

وفي ذلك اعتبار لتركيب الجملة، فقوى ذلك الوجه، إذ جرى صدر الكلام على إلى آخره، لنطابق الكلام، وربط صدر الكلام بعجزه، لذللك فهو المختار عند مكيّ. الر ابعة: التخفيف و التثقيل
yx w v u t s

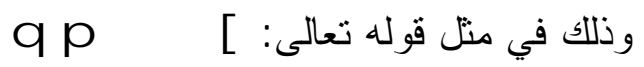

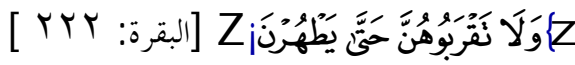

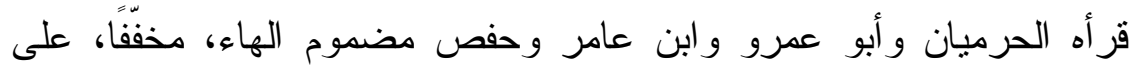

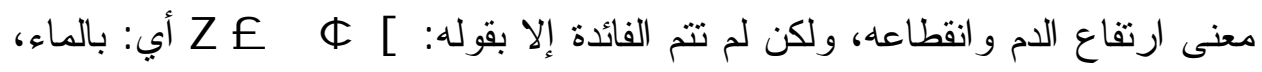

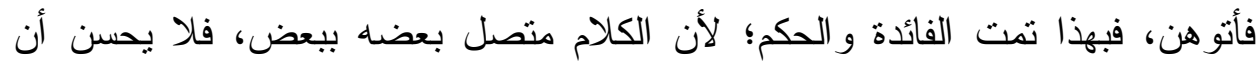

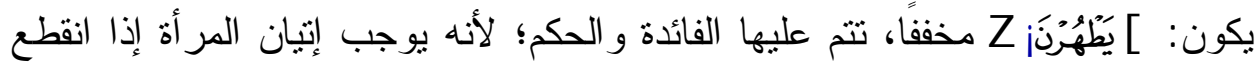




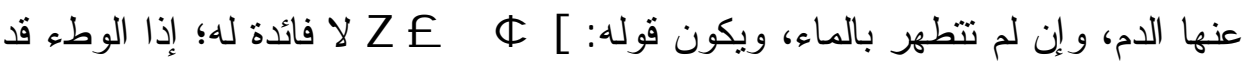
يتم بزو ال الدم، فلابد من اتصال، فإذا تطهرن بما قبله، وبه يتم الحكم، و الفائدة في أن لا توطأ الحائض إلا بانقطاع الدم، و التطهير بالماء، فلو حمل الأول على التشديد، وفتح

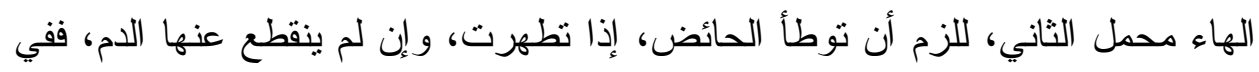

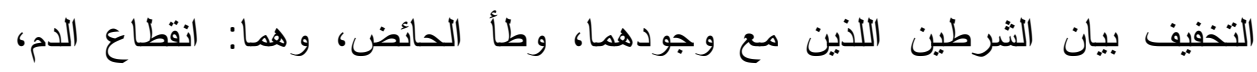

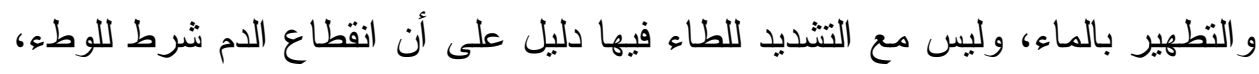

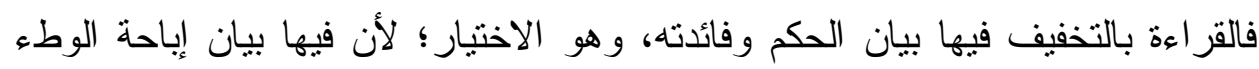

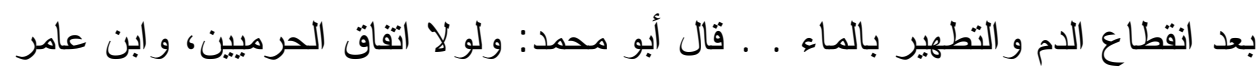

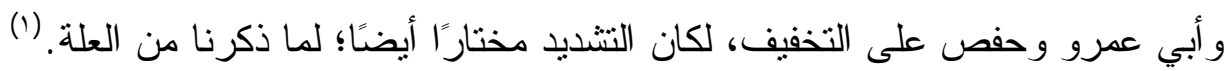

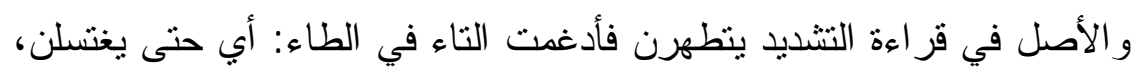

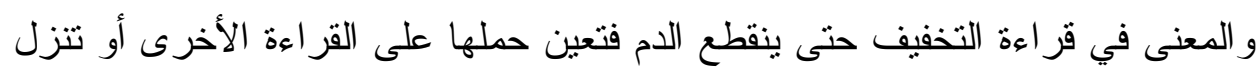

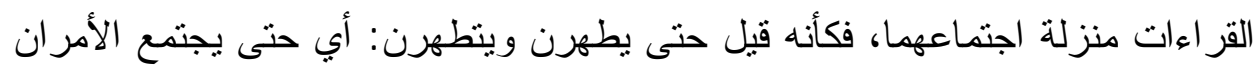

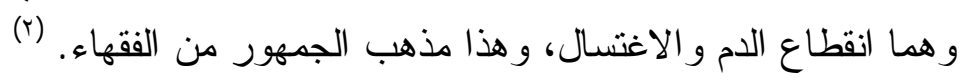

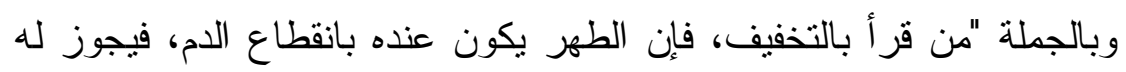

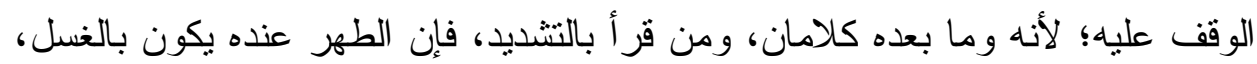

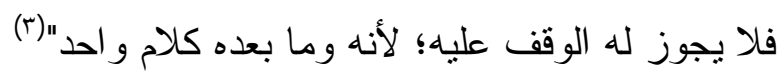

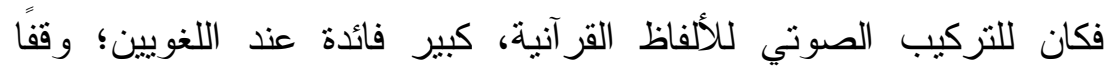

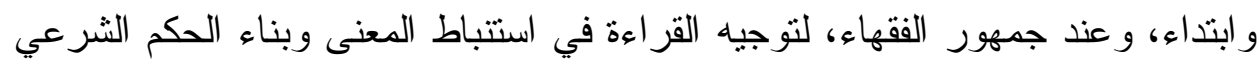
على هذا النتاغم الصوتي و اختلاف التركيب المؤدى عنه . ومنتكه قوله تعالى: ]

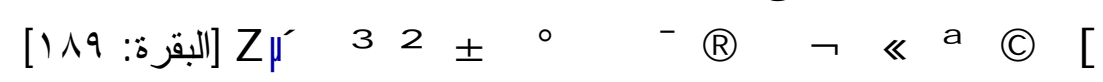

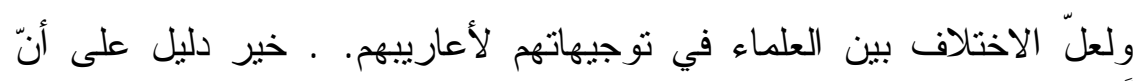
در اسة النَُّْْ على أساس المعنى ضرورة ملحّة، تكسب الموضوع جدّةً وطر افةً، وتزيد 
المسألة عمقاً ونضوجًا، وتكسب العقل قوّةً ولياقةً، وتضفي على المقام مرونةً ولطافة،

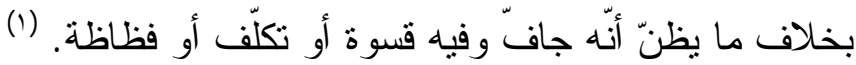

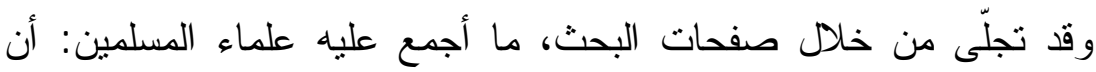
الاختلاف في القراءات إنما هو اختلاف تتوع وتغاير، لا اختلاف تضاد وتتاقض. 
المبحث الثاني: دور القراعات في بناء التركيب الصوتي وآثاره اللغوية والدلالية

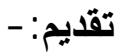

قد وضح مما سبق أنه قد لوحظ في اختلاف القراءات المتواترة أن لهذه القراءات و اختلافها أثزا و اضحا في مناح كثيرة معنوية ودلالية، ومن ور اءها فقهية

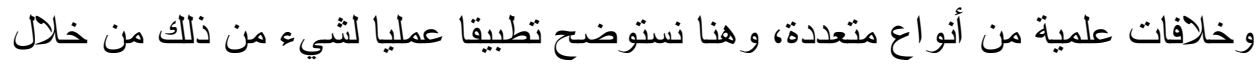

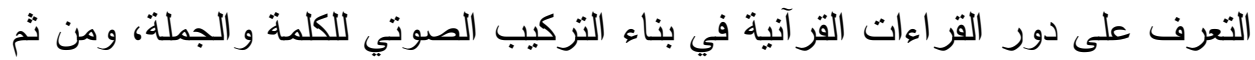
آثار هذه اللغوية بعامة و الدلالية بخاصة، وهو ما نتعرف عليه من خلال هذا المبحث، لئ،

و الذي يحتوي على مطلبين اثنين هما: -

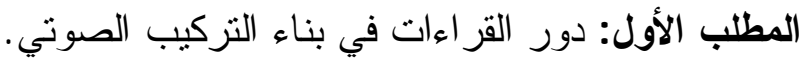
المطلب الثاني: آثار القر اءات اللغوية و الداءلاءلية. المطلب الأول: دور القراءات في بناء التركيب الصوتي تبادل الحروف في الكلمات وتناوب الوظائف في التركيب الصوتي لهذه الكلمات، له كبير أثز في بناء النص القرآني .

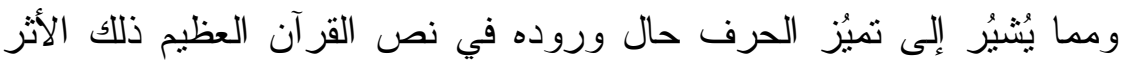
الذي يُحْثنه التركيب الصوتي لكلمات القر آن في ذات المُستمع حتى و إنْ لم يكن عقله

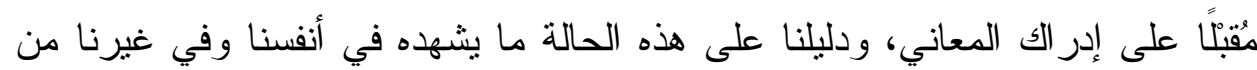

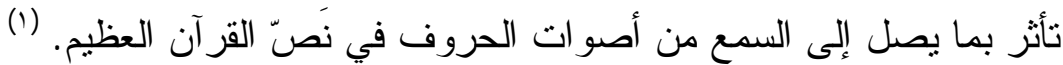

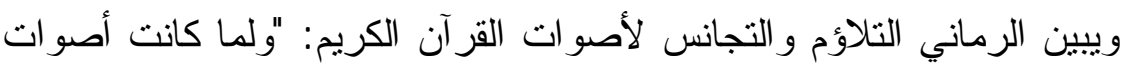

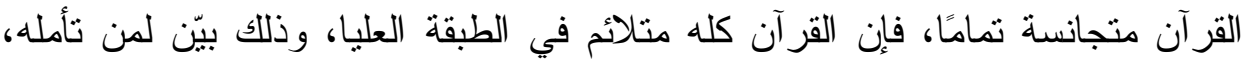
و الفرق بين القرآن وبين غيره من الكلام في تلاؤم الحروف على نحو الفرق بين

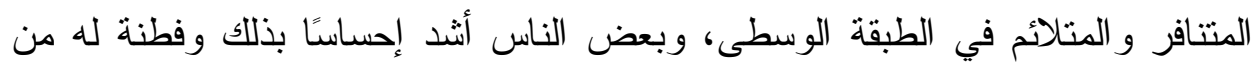
بعض " (r)

$$
\text { *فاستبان أن التلاؤم في أصوات القر آن من وجوه: }
$$

السبب في التلاؤم ويعود به إلى تعديل الحروف في التأليف، فكلما كان أعدل

كان أثند تلاؤماً.

(1) (1) اللباب في أم الكتاب، محمد مبارك المزيودي (ص: V0).

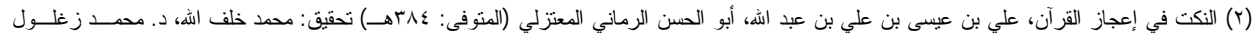


و الفائدة في التلاؤم، يعود بها إلى حسن الكلام في السمع، وسهولته في اللفظ،

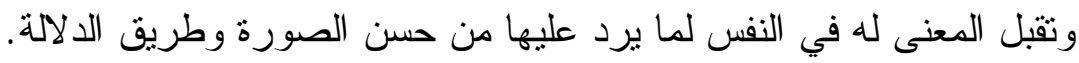

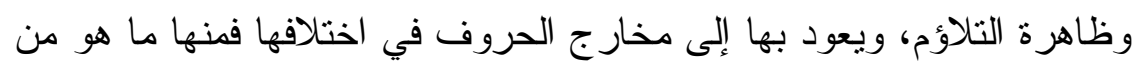

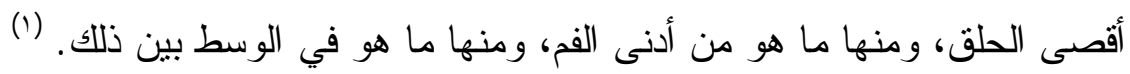

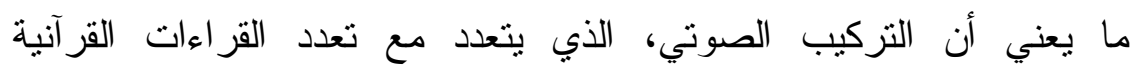

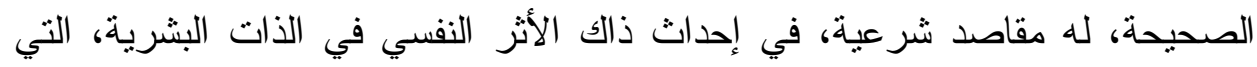

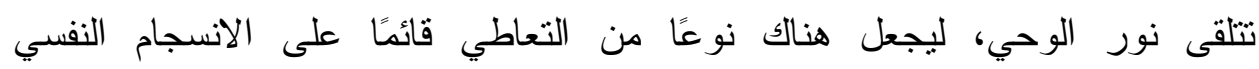

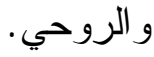

\section{تطبيقات لهذا (المعنى}

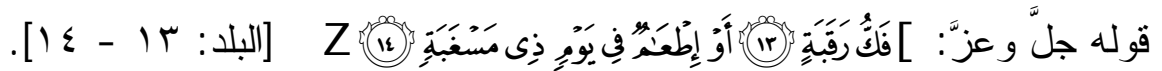

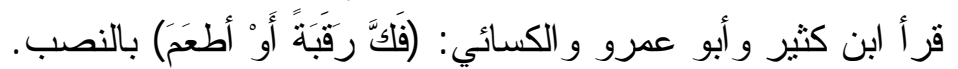

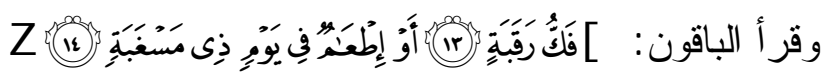

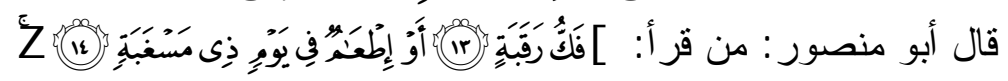

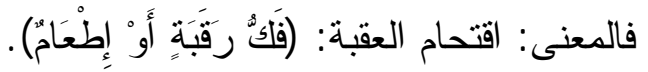

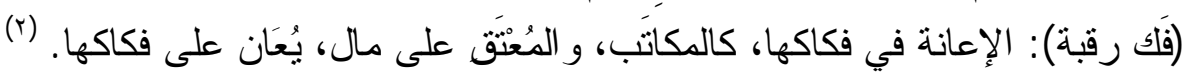

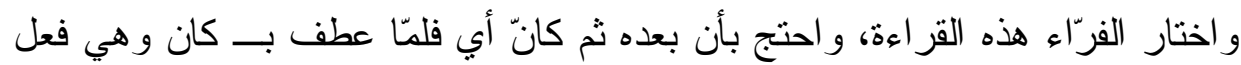

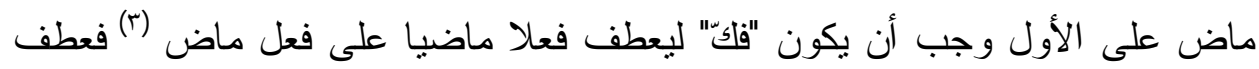
عليه بالفعل الماضي، فوجب أن يكون ما قبله بلفظ الماضي، ليتفقا في اللفظ وكما هو

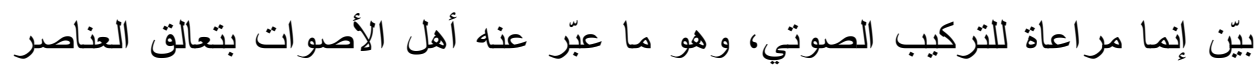
المشكّة له. 
قال أبو علي الفارسيّ (1): وزعموا أن أبا عمرو احتج لقراءة: (فلكَّ رقبةً) بقوله: فعلًا وجب أن يكون المعطوف عليه مثله. (r) وذهب جمع كبير من النحويين و اللغويين إلى اختيار المصدر ظهر ذانه ذلك عند

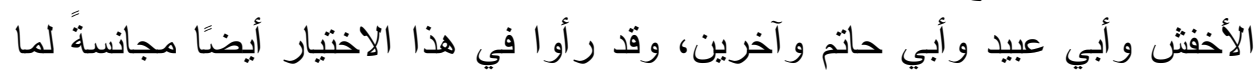

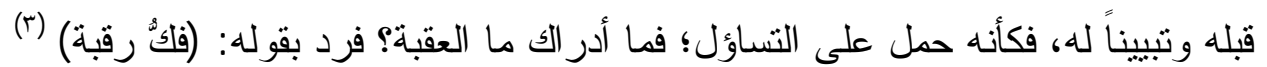

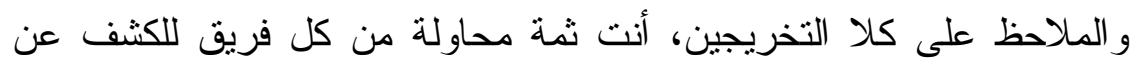
وجه من وجو المجانسة في التركيب الصوتي في القراءة الواحدة. ومثلكه قوله تعالى: B B C

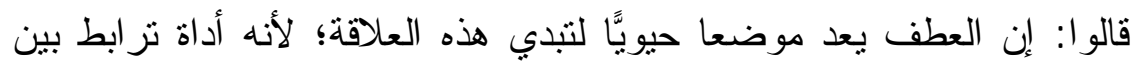

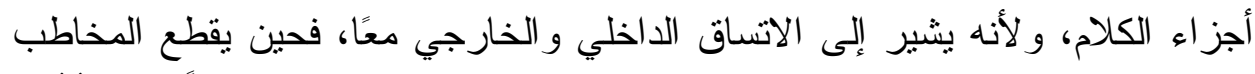

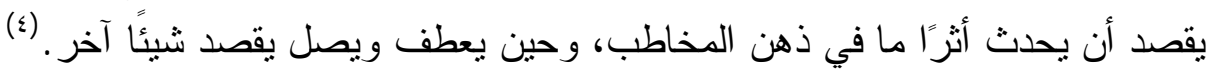

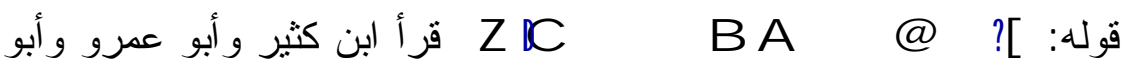
بكر : (ونكفر) برفع الراء على الاستئناف، يقول الله جل وعز (ونحن نكفر) وحجته

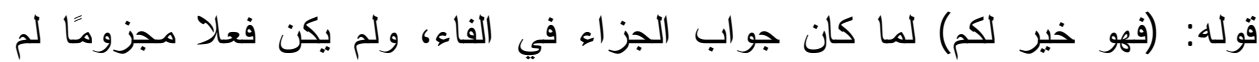

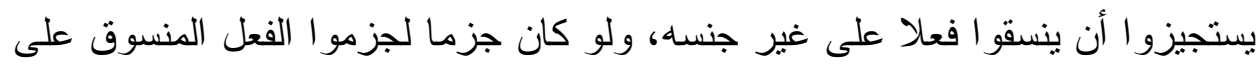

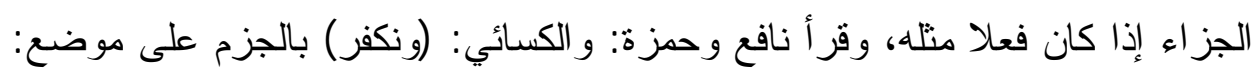

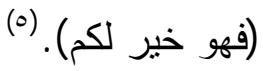
إن السياق الداخلي يتحدد بحسب مكوناته، وهو ما يعيدنا إلى قولهم: لكل كلمة

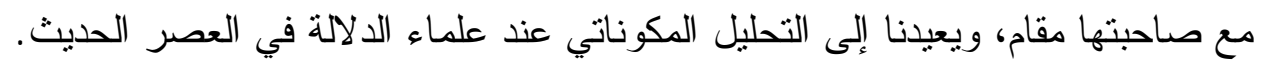


قر أ ابن عباس: (وتكفر ) يكون معناه وتكفر الصدقات، وقر اعة عكرمة: (وتكفر

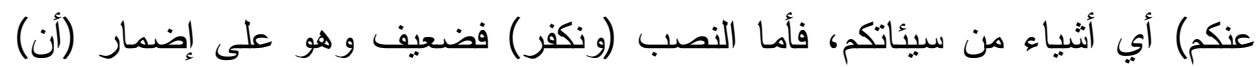

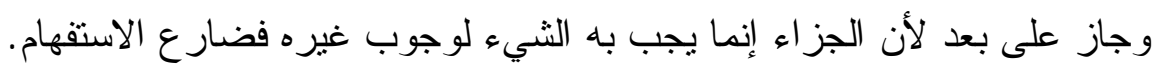

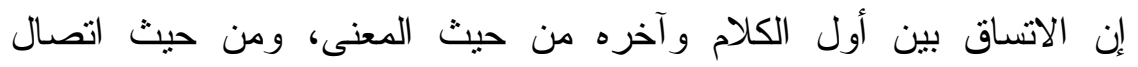

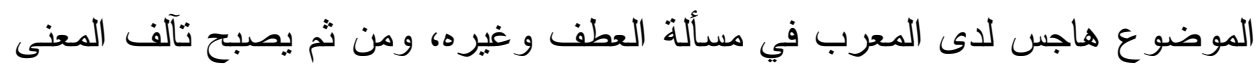

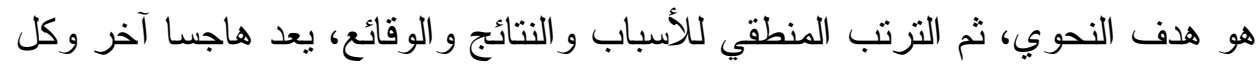

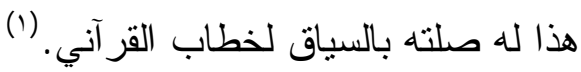
لذلك ظهرت مجموعة من الألفاظ و المصطلحات في صفحات الدراسات التي تتتاول التركيب الصوتي و الدلالي لآيات القرآن منل (المشاكلة) و (اللياقة) (ما يليق)

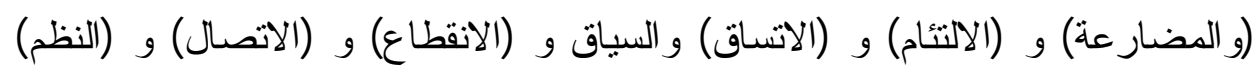

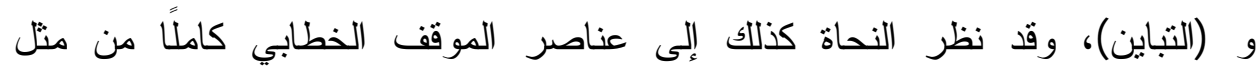
استحضار المخاطب وما يليق في حقه، و المخاطب وما يناسبه من وجوه الخطاب

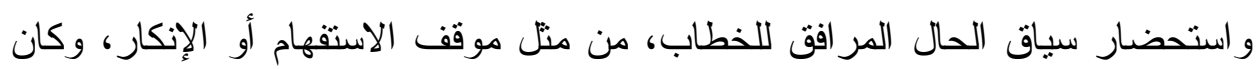
المعرب يقبل وجها أو يستبعد وجها آخر بالاتكاء على هذه المسائل و غير ها. المطلب الثاني: آثار القراعات اللغوية والدالالية.

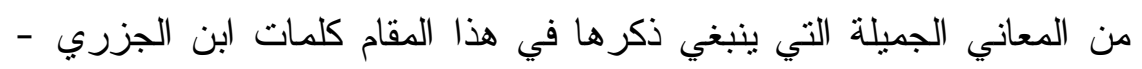

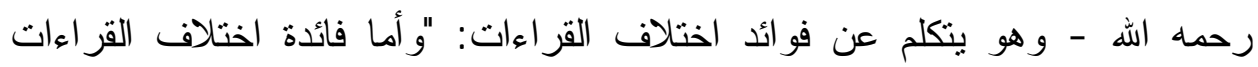

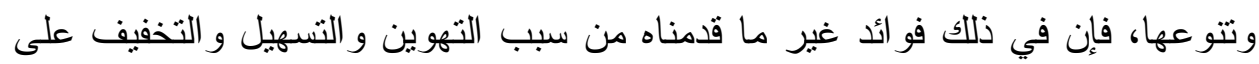

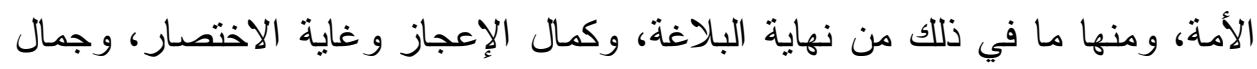

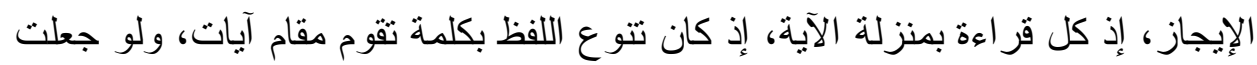

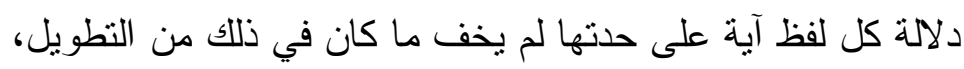

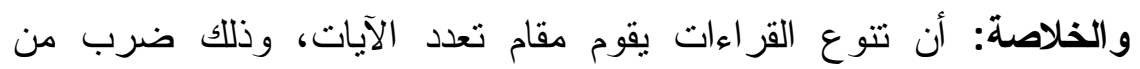

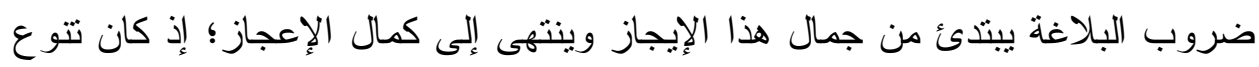

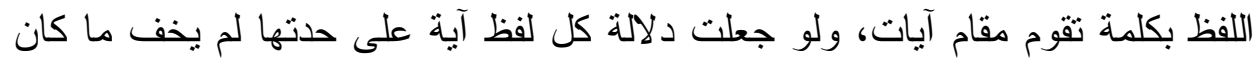

في ذلك من التطويل . (r) 
وهو ما قاله شيخ الإسلام ابن تيمية: "إن القراعتين كالآيتين، فزيادة القراءات

كزيادة الآيات" (1)

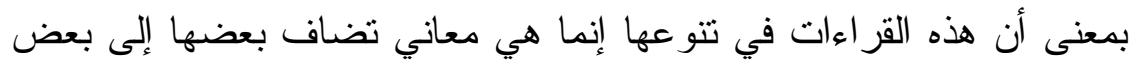

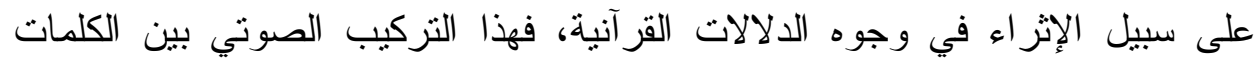
يتتوع فنتنوع معه المباني الدلالية. هذا الاختلاف في القراءات و التتوع في التركيب الصوتي أكسب المفسرين

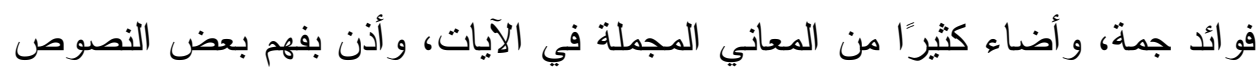

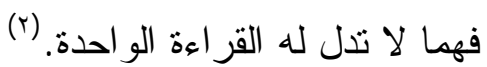
وقد ذكر العلماء أن ثمة اختلافا دلاليَّا مترثبًا على ثتاوب الحركات، فما باللك و الحروف و الكلمات . ت ونمات

\section{تطبيقات لهذا المعنى:}

ومن أبين الأمتلة في الدلالة على مجانسة التركيب الصوتي للمباني الدلالية: -

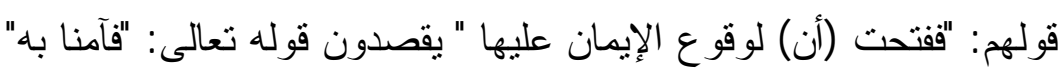

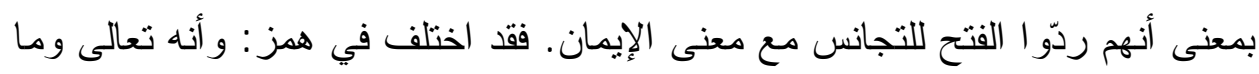

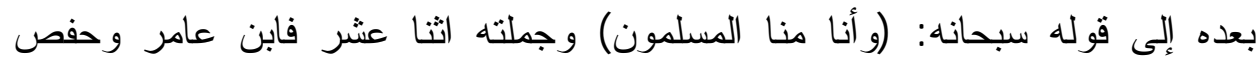
وحمزة و الكسائي وخلف بفتح الهزةة فيهن عطفا على مرفوع أوحى .. وقر أ أبو جعفر

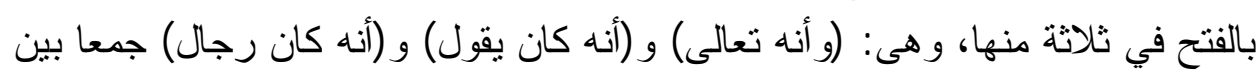

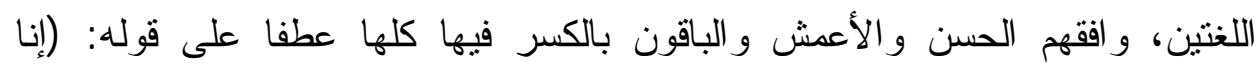

(r) (معنا)

فاجتمع القر اء على كسر (إنا) في قوله: (فقالو ا إنا سمعنا قر آنا عجبا) واختلفو ا فيما بعد التحا

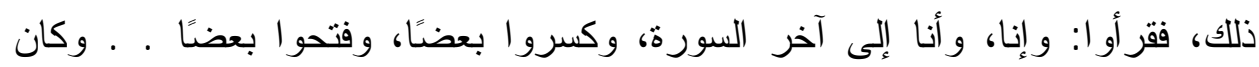

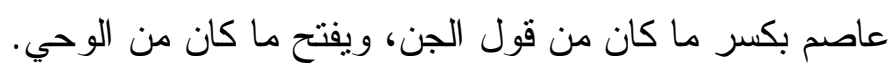


فأما الذين فتحو ا كلها فإنهم ردوا (أن) في كل السورة على قوله: فآمنا به، و آمنا بكل

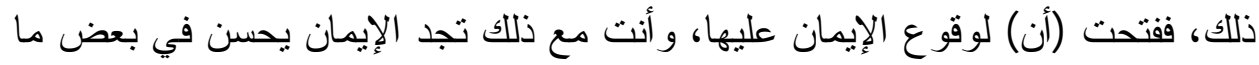

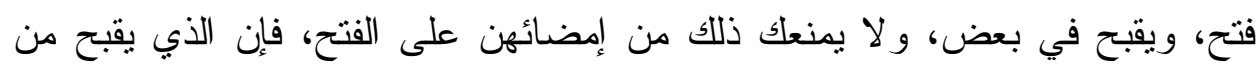

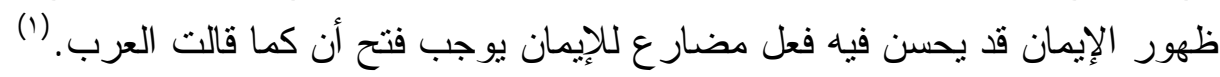

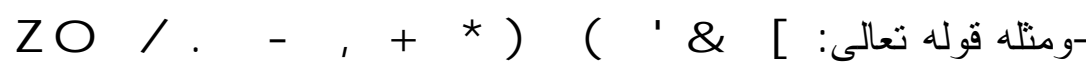

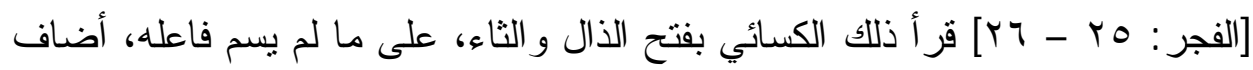

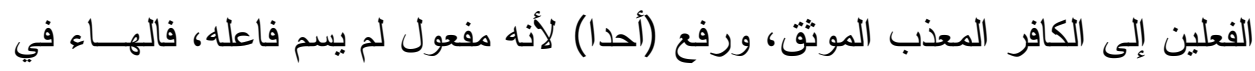

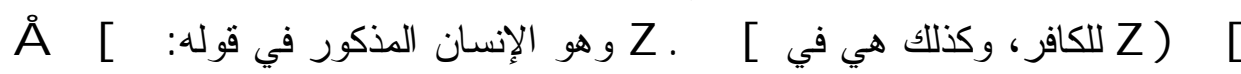
ZE É É Ç AE

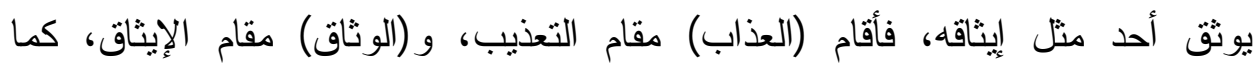

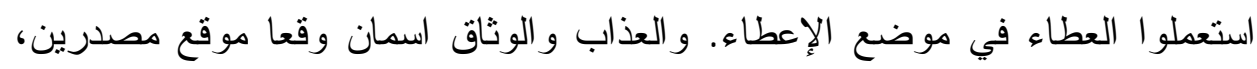

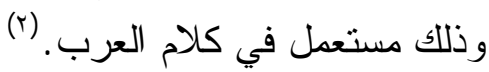
قال أبو علي الفارسيّ: "و اختاره الثيخ أبو عمرو ليفيد المعنى زيادة عذاب هذا الإنسان

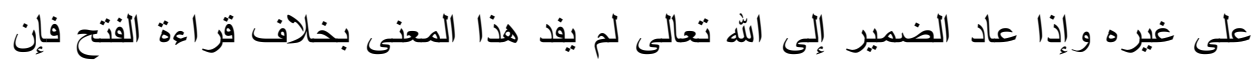
على كلا التقديرين يحصل هذا المعنى؛ فإن الهاء إن عادت على على الإنسان فظاهر على هلى إنى ما سبق و إن عادت على الله تعالى كان المعنى لا يعذب أحد مثل تعذيب اله تعالى لهذا

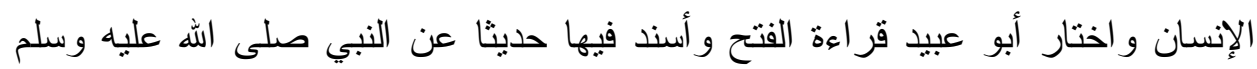

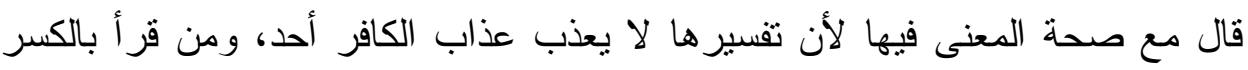
فإنه يريد لا يعذب عذاب اله عز وجل أحد، قال: وقد علم المسلمون أنه ليس يوم

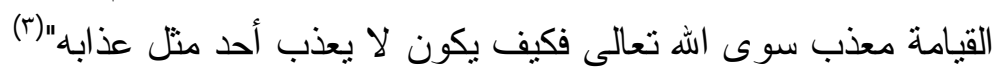

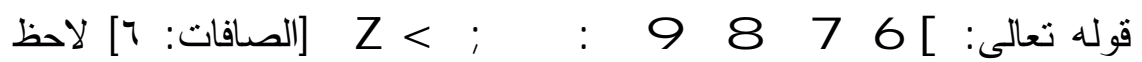
الدارسون للقراءات مناسبة القراءات و المعاني الدلالية، و التي تساير التفسير العلمي

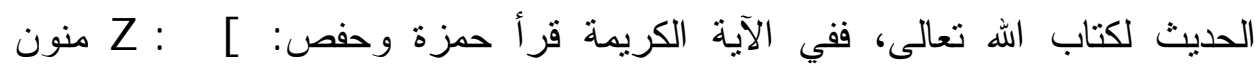
جر ج ; 
مررت بأبي عبد اله زيد المعنى أنا زينا السماء بالكو اكب، وبدل المعرفة من النكرة جيد، ونظير هذا في القرآن:

ZZH GF E DCBA @? > > ; : 9 [ [الثورى: or - or ] فأبدل المعرفة من النكرة.

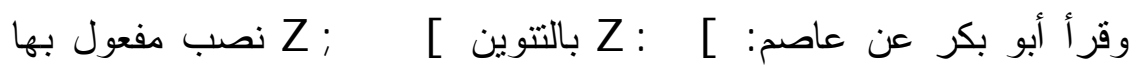

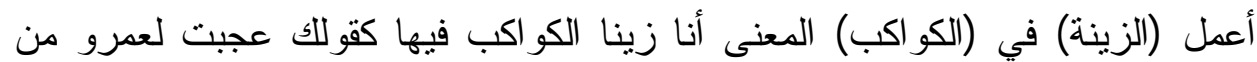

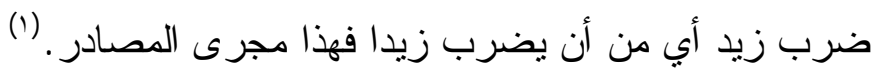

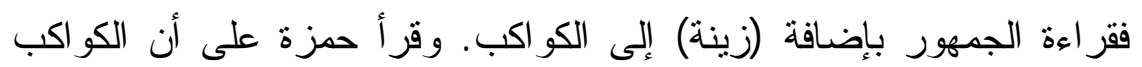

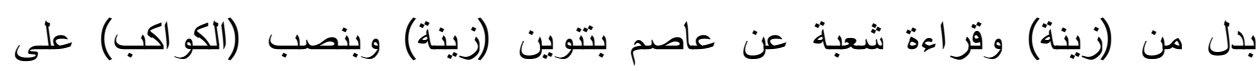
الاختصاص بتقدير : أعني

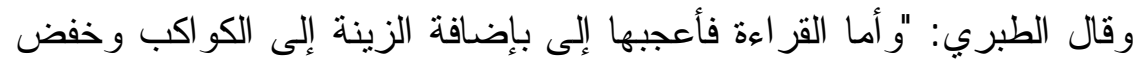

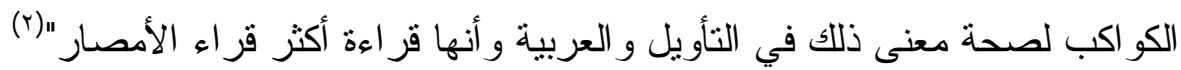

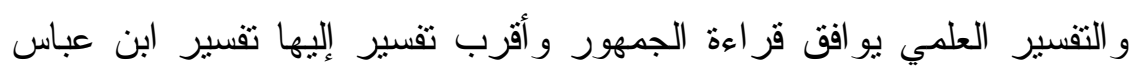

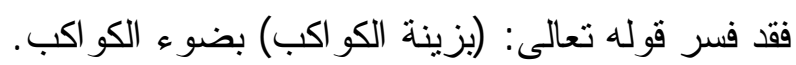

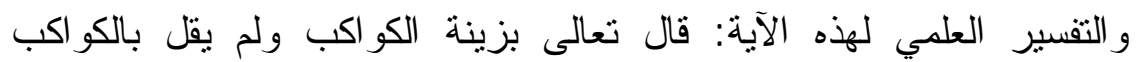
فيستل من ذلك أن ضوء الكواكب الذي هو زينتها ليس في ذاتها وليس منها بل هو عارض عنها أي ضوء مكتسب ومعكوس، و هذا التفسير قد اعتمد على قر اعة الجمهور

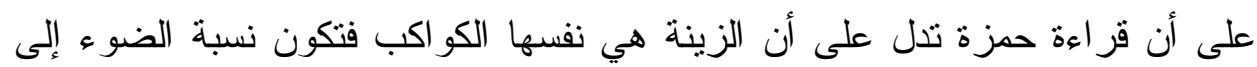

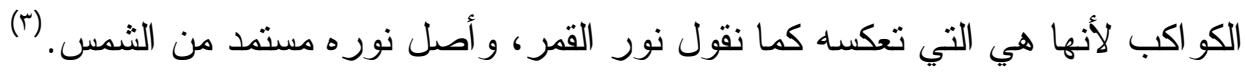

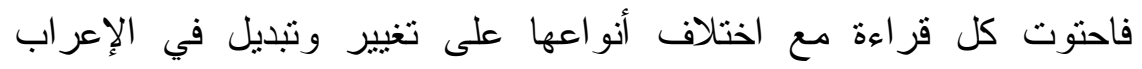
و الدلالة و التركيب، كل هذا في نسق؛ وذلك لكون هذه الأشياء مرتبطة المعاني متشابكة الأداء في إحداث التأثير والتتاغم والاتفاق على التغيير المطلوب في التفاعل مع الفهم المستجد كل مرة تفرق في القراءة عن أختها، وهو الذي أردنا طرحه ومناقتشته من

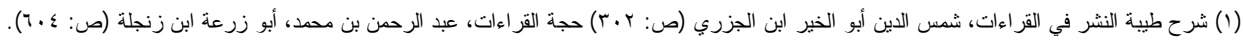

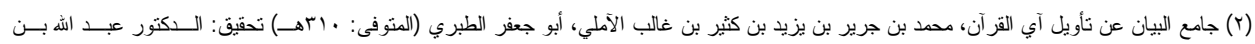

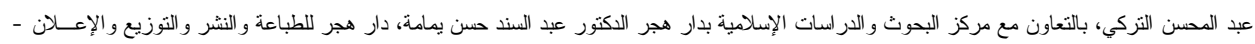

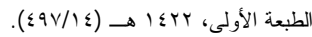

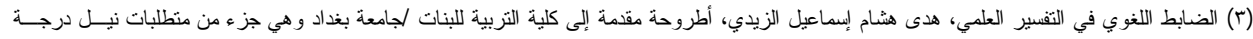

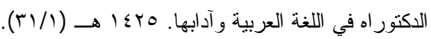


خلال هذه الدراسة، والتي نرى أن الحديث فيها منسع ومرتع خصيب ربما يحتاج إلى هذ غير هذا كثير من الطرح و الارس. 


\section{الخاتمة}

$$
\text { وتحتوي على: }
$$

النتائج:

$$
\text { استبان من خلا البحث: }
$$

ا - أن القراءات القر آنية هي تلك الصور المشروعة لقرة اعة القرآن بحيث يتميز في

$$
\text { أدائه وتركيبه ومعانيه. }
$$

r - الصوت هو ذللك التناغم السمعي المركوز في الفطرة السوية. r - المعنى هو تلك الدلالات الو اقعة في النفس من سماع النص النص و التأثر به .

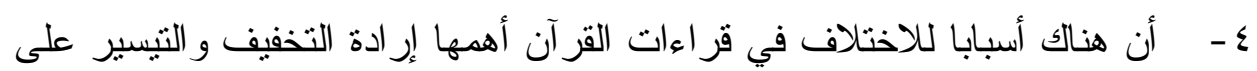

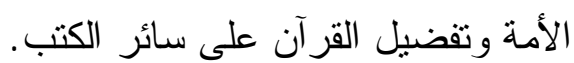

ه - أن الاختلاف في القراءات القرآنية يثري النص القرآني بمعان جديدة تسهم في

$$
\text { النو احي الفقهية و اللغوية و غير ها. }
$$

7 - اختلاف القراءات بغير في اختلاف التركيب في الجملة وينقلها إلى أطوار متغايرة من التعبير في الصورة المعنوية المتقاربة

V - أدى الاختلاف في القر اءة في بناء التركيب الصوتي في الجملة بحيث تتاسق كل اختلاف في تتاغم صوتي متتاسق متتاسب. 1 - أثز في المعاني و الدلالات بحيث نشأت دلالات أكثر في التعبير و آثز في أحيان في التزجيح الفقهي و اللغوي.

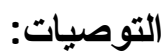
ا - التوصية ملحة إلى ترجمة الدور القرآني في الخلاف في قراعته إلى معان

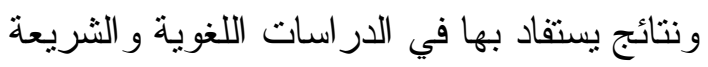
r - تشجيع المحاولات قائمة في هذا السياق لتسليط الضوء على على جمال البحث

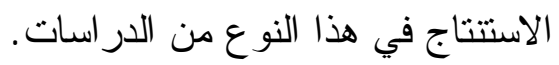
r - الحرص على أن يكثف نرجمة تللك العلاقة القوية بين القراءات و الثزاء اللغوي لاءئي و التركيبي . 
مصادر البحث:

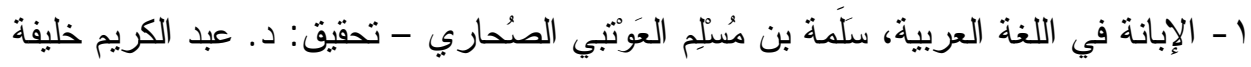

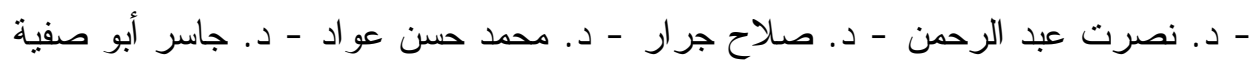

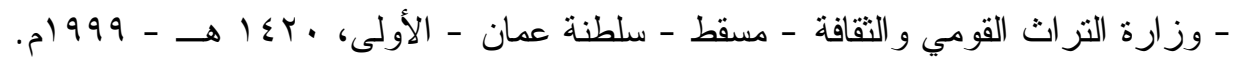

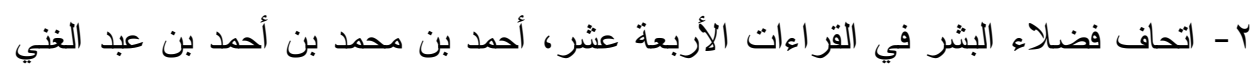

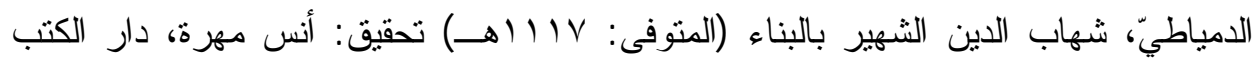

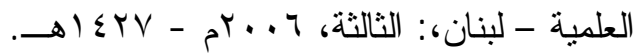

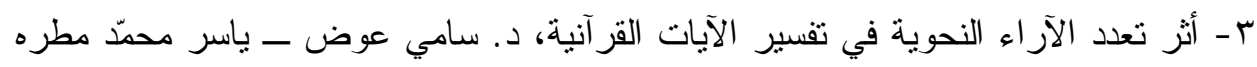
جي، مجلة جامعة تشرين للار اسات و البحوث العلمية ـ سلسلة الآداب و العلوم الإنسانية مجلد الآداث . ـ - إعراب القراءات السبع وعلاها، الحسين بن أحمد بن خالويه، أبو عبد الله (المتوفى: .

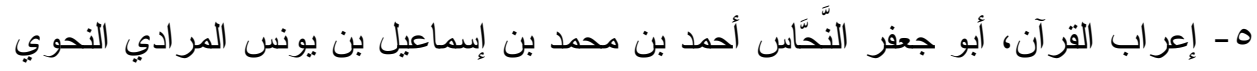

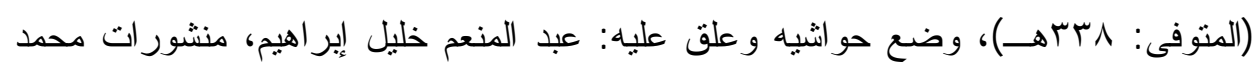

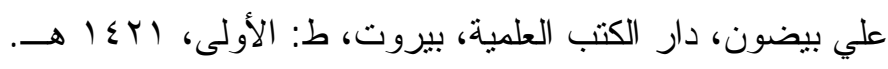

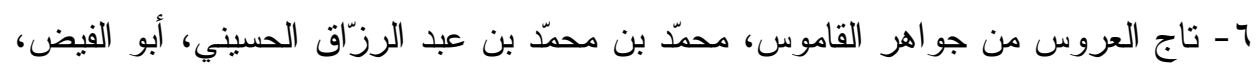

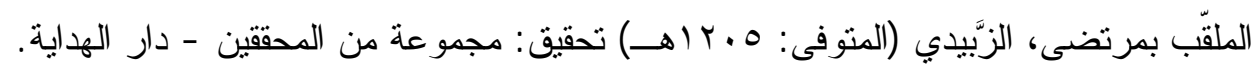

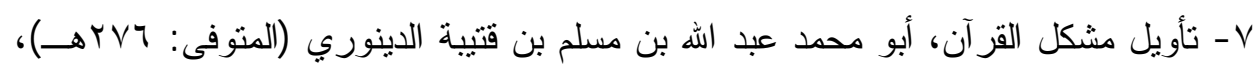

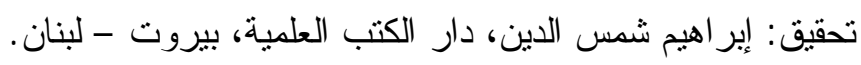

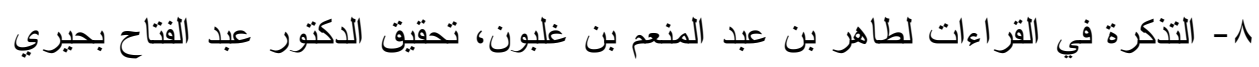

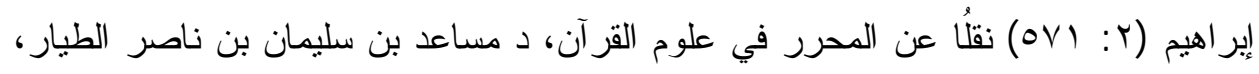

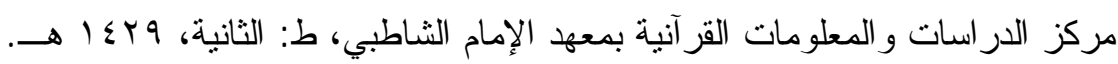

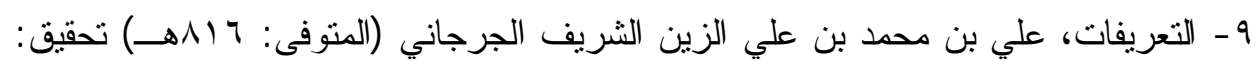

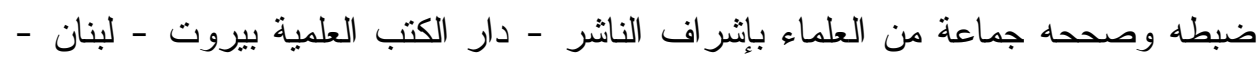

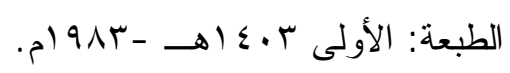


• 1 - تفسير الماوردي = النكت و العيون، أبو الحسن علي بن محمد بن محمد بن حبيب

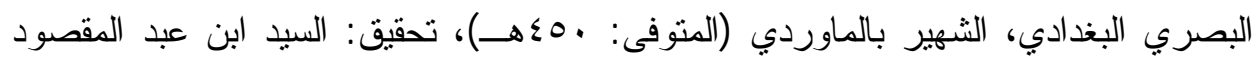

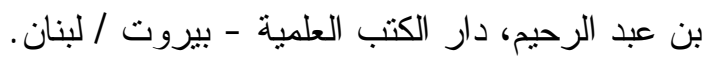

1ا - أتيسير في القراءات السبع، أبو عمرو عثمان بن سعيد الداني الأندلسي (المنوفى:

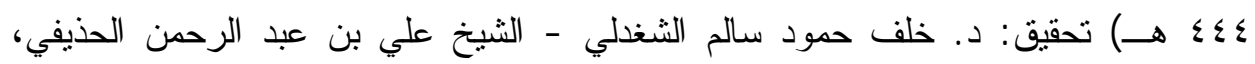
و الثيخ عبد الر افع بن رضوان بن علي الثرقاوي - دار الأندلس للنشر و التوزيع، حائل - ل

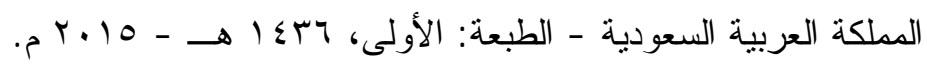

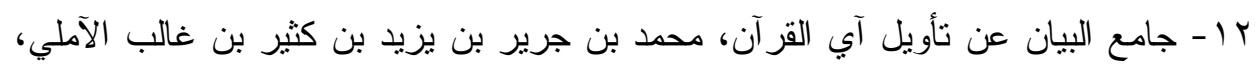

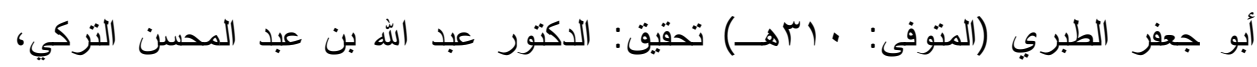
بالتعاون مع مركز البحوث والدراسات الإسلامية بدار هجر الدكتور عبد السند حسن يمامة، الدئ،

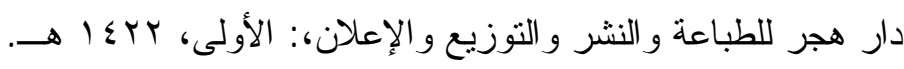

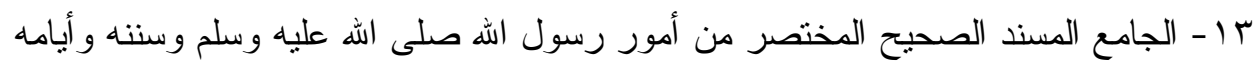

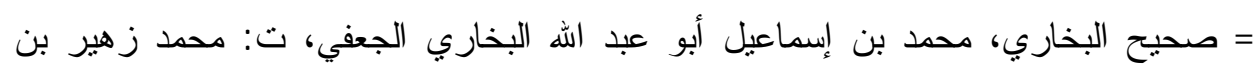

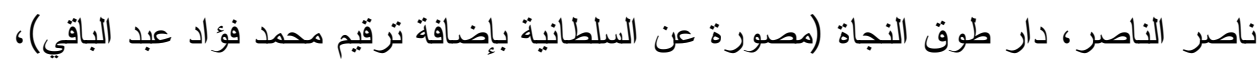

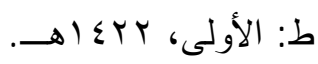
ع ا - حجة القراءات، عبد الرحمن بن محمد، أبو زرعة ابن زبن زبلة (المتوفى: حوالي r.ءــا) تحقيق : الكتاب ومعلق حواثيه: سعيد الأفغاني، دار الرسالة.

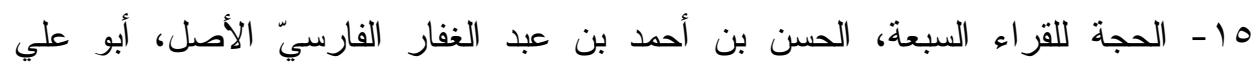

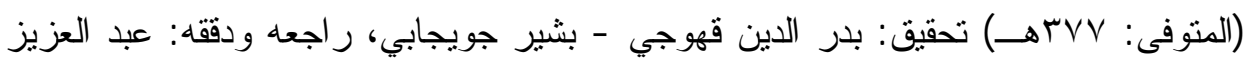

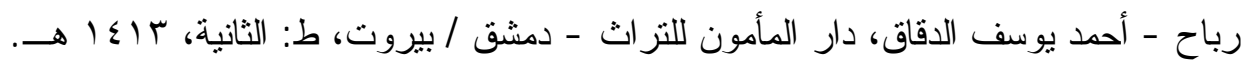

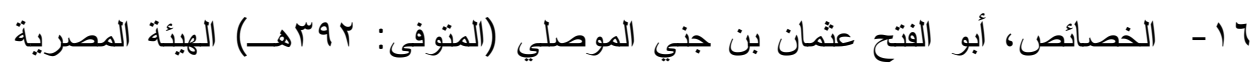
العامة للكتاب - الطبعة الر ابعة.

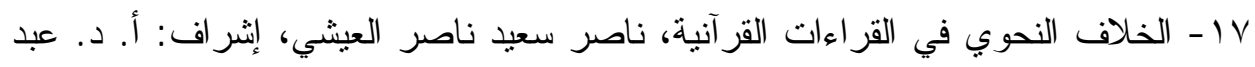
الله أحمد الجبوري، أطروحة تقدم بها المؤلف إلى مجلس كلية الآداب في الجامعة آلته المستتصرية، وهي جزء من منطلبات نيل درجة دكتوراه فلسفة في اللغة العربية وآدابها

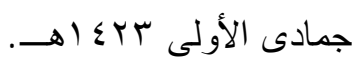


^ا - شرح طيبة النشر في القراءات، ابن الجزري (ت: بr/هـ)، ضبطه وعلق عليه: الثيخ

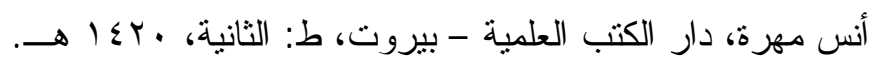
9 1 - صفحات في علوم القراءات، د. أبو طاهر عبد القيوم عبد الغفور السندي، المكتبة

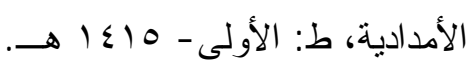

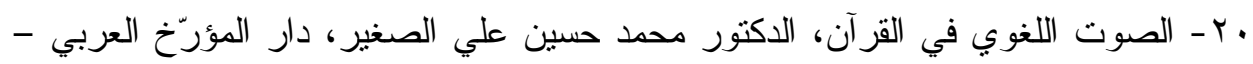

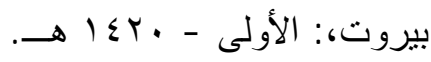
اب - علوم القرآن عند شيخ الإسلام ابن نيمية، بجاد بن حمود بن محمد العماج، إثراف: أ. د. إبر اهيم بن سعيد بن حمد الدوسري.

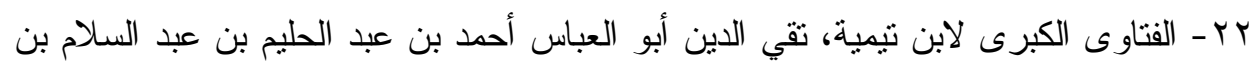

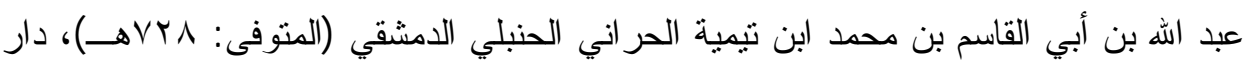

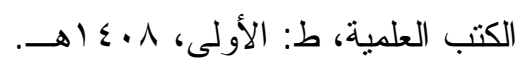
بr - القر اءات المنو اترة و أثز ها في الرسم القر آني و الأحكام الشرعية، محمد حبش، دار الفكر

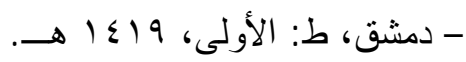

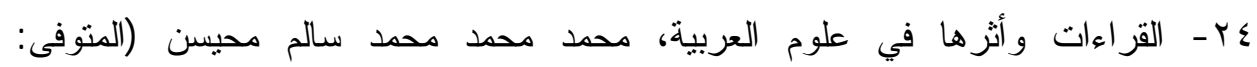

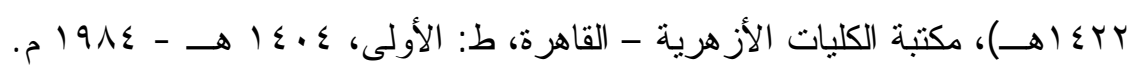

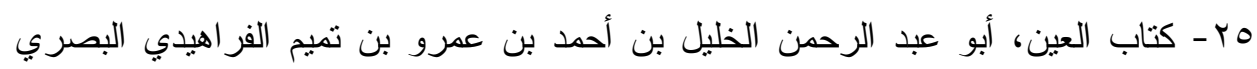

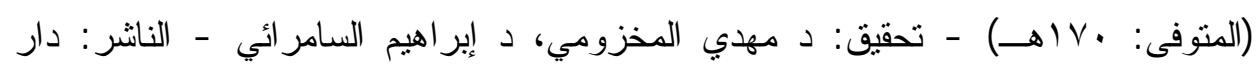
و مكتبة الهلال.

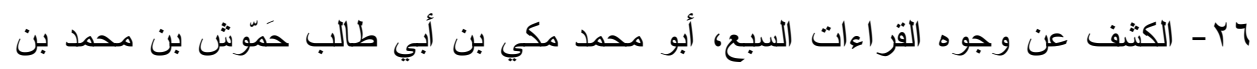

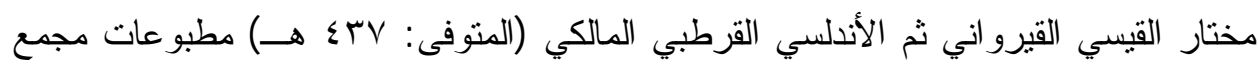

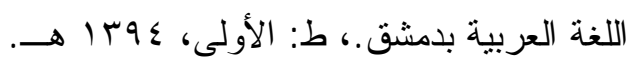

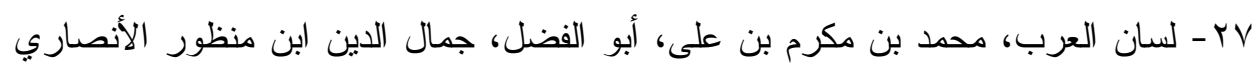

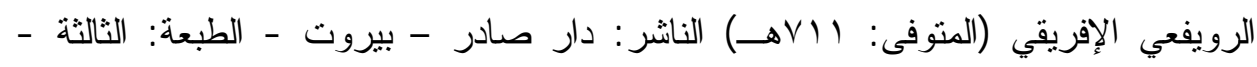
$\rightarrow 1 \leqslant$ ^ץ - مجموع الفتاوى، تقي الدين أبو العباس أحمد بن عبد الحليم بن تيمية الحر اني (المتوفى:

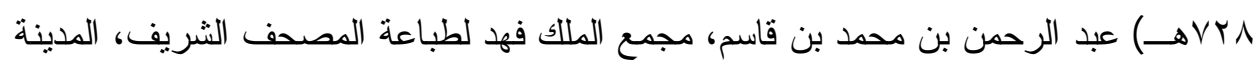

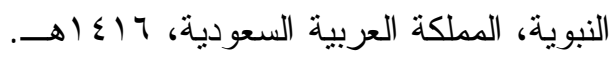


وب - المسند الصحيح المختصر بنقل العدل عن العدل إلى رسول اله صلى اله عليه وسلم،

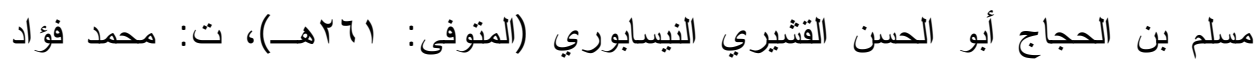

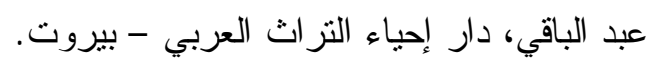
• ب - معاني القر اءات للأزهري، محمد بن أحمد بن الأزهري الهروي، أبو منصور (المتوفى :

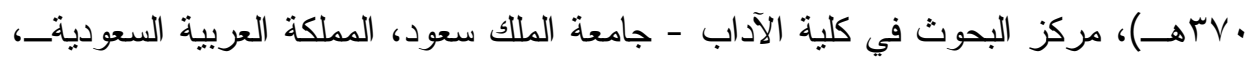

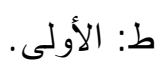
اب - المعجم المحيط، أديب اللجمي -شحادة الخوري - البشير بن سلامة -عبد اللطيف عب - ن البل

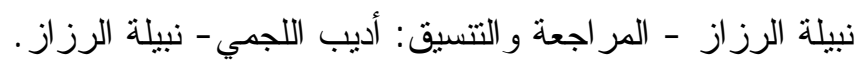

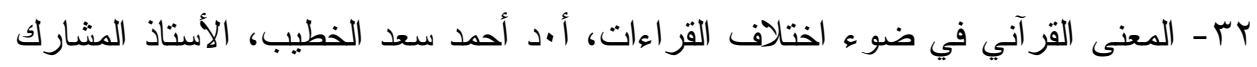

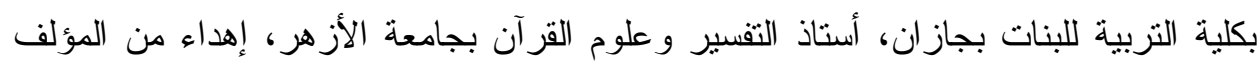
وفقه الله لنبكة التفسير و الدر اسات القر آنية.

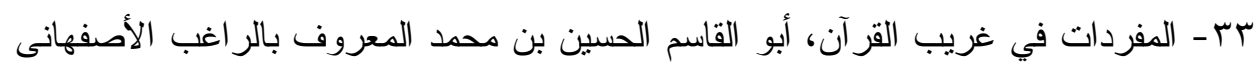

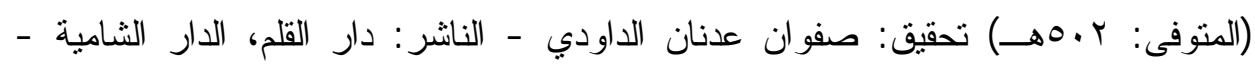

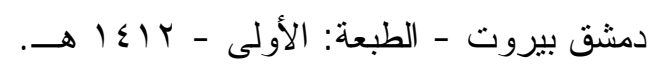

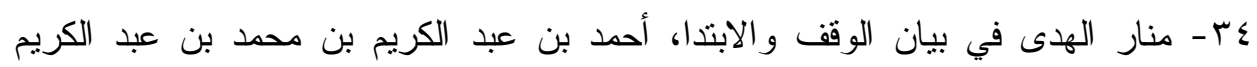

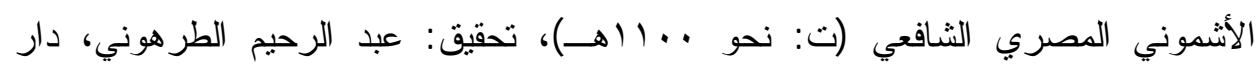

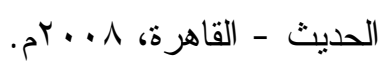

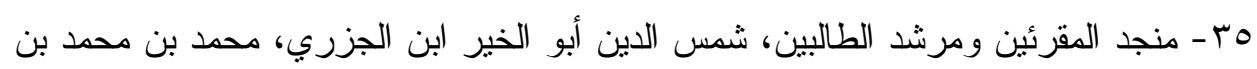

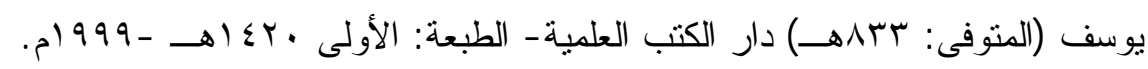

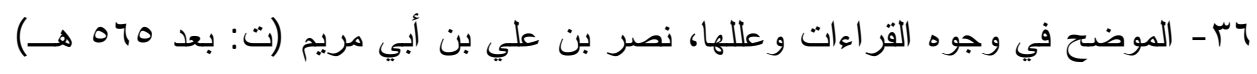

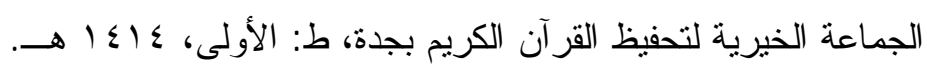

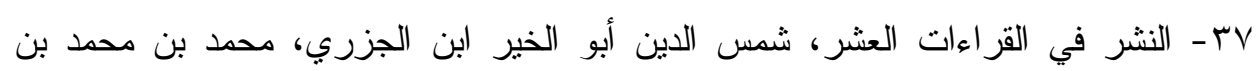

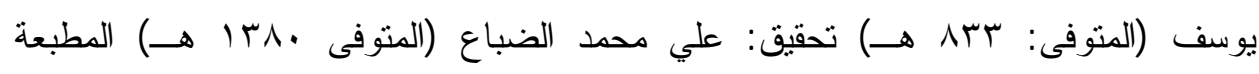
التجارية الكبرى - تصوير دار الكتاب العلمية. ^r - النكت في إعجاز القرآن، علي بن عيسى بن علي بن عبد الله، أبو الحسن الرماني

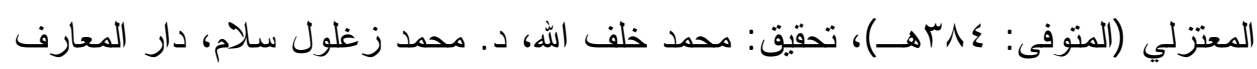

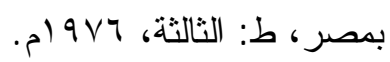

